\title{
Effects of climate change and adaptation on the livestock component of mixed farming systems: A modelling study from semi-arid Zimbabwe
}

\author{
Katrien Descheemaeker ${ }^{\mathrm{a}, *}$, Mink Zijlstra ${ }^{\mathrm{a}}$, Patricia Masikati ${ }^{\mathrm{b}}$, Olivier Crespo $^{\mathrm{c}}$, \\ Sabine Homann-Kee Tui ${ }^{\mathrm{d}}$ \\ ${ }^{a}$ Plant Production Systems, Wageningen University, PO Box 430, 6700 AK Wageningen, The Netherlands \\ b World Agroforestry Centre (ICRAF), Lusaka, Zambia \\ c Climate System Analysis Group, Environmental and Geographical Science Dept., University of Cape Town, Rondebosch, South Africa \\ d International Crops Research Institute for the Semi-Arid Tropics (ICRISAT), P O Box 776, Matopos, Bulawayo, Zimbabwe
}

\section{A R T I C L E I N F O}

\section{Keywords:}

Crop-livestock interactions

Forage

Soil fertility

Vulnerability

Resilience

Crude protein

Metabolizable energy

\begin{abstract}
A B S T R A C T
Large uncertainties about the impacts of climate change and adaptation options on the livestock component of heterogeneous African farming systems hamper tailored decision making towards climate-smart agriculture. This study addressed this knowledge gap through the development and use of a dynamic modelling framework integrating climate, crop, pasture and livestock models. The framework was applied to a population of 91 farms located in semi-arid Zimbabwe to assess effects on livestock production resulting from climate change and management interventions. Climate scenarios representing relative "cool-wet", "hot-dry" and "middle" conditions by mid-century (2040-2070) for two representative concentration pathways were compared with the baseline climate. On-farm fodder resources and rangeland grass production were simulated with the crop model APSIM and the pasture model GRASP respectively. The simulated fodder availability was used in the livestock model LIVSIM to generate various production indicators including milk, offtake, mortality, manure, and net revenue. We investigated the effects of two adaptation packages targeting soil fertility management and crop diversification and quantified the sensitivity to climate change of both current and improved systems. Livestock productivity was constrained by dry-season feed gaps, which were particularly severe for crude protein and caused by the reliance on rangeland grazing and crop residues, both of low quality in the dry season. Effects on grass and stover production depended on the climate scenario and the crop, but year-to-year variation generally increased. Relative changes in livestock net revenue compared to the baseline climate varied from a $6 \%$ increase to a $43 \%$ decrease, and the proportion of farmers negatively affected varied from $20 \%$ to $100 \%$, depending on the climate scenario. Adverse effects of climate change on average livestock production usually coincided with increased year-to-year variability and risk. Farms with larger stocking density faced more severe feed gaps and were more sensitive to climate change than less densely stocked farms. The first adaptation package resulted in increased stover production and a small increase in livestock productivity. The inclusion of grain and forage legumes with the second package increased milk productivity and net revenues more profoundly by $30 \%$. This was attributed to the alleviation of dry-season feed gaps, which also reduced the sensitivity to climate change compared to the current system. Clearly, individual farms were affected differently by climate change and by improved farm management, illustrating that disaggregated impact assessments are needed to effectively inform decision making towards climate change adaptation.
\end{abstract}

\section{Introduction}

Smallholder farming systems are vulnerable to climate change and likely to be adversely affected to varying extents across sub-Saharan Africa (Naab et al., 2012; Descheemaeker et al., 2016a). Mixed croplivestock systems are the predominant farming system throughout the semi-arid and sub-humid zones of the continent with important contributions to meat and milk production, to crop production through the provision of traction and manure, and to livelihoods for millions of rural people (Herrero et al., 2010; Tarawali et al., 2011). To improve the resilience of these farming systems, context-specific information is needed for effective decision making and for the selection and implementation of strategies towards climate-smart agriculture (Lipper et al., 2014; Thornton and Herrero, 2014). However, large

\footnotetext{
* Corresponding author.

E-mail address: katrien.descheemaeker@wur.nl (K. Descheemaeker).
} 
uncertainties and knowledge gaps persist about the likely effects of climate change and adaptation options, in particular for effects on the livestock component (Weindl et al., 2015) and for heterogeneous farm populations (see Descheemaeker et al. (2016a) for a review of the gaps).

Farming systems in sub-Saharan Africa are diverse, with enormous heterogeneity between households in terms of objectives, attitudes and access to natural, financial, physical, human and social capitals (Giller et al., 2011; Descheemaeker et al., 2016b). Hence, the impact of climate change and adaptation options is likely to differ between farm types (Masikati et al., 2015; Traore et al., 2017), and should not be generalized in impact assessments (Thornton et al., 2007). Integrated assessments can inform strategies towards climate-smart agriculture (Claessens et al., 2012; Antle et al., 2016), but need data produced with detailed, process-based models that allow simulating the effects of climate and adaptation options on the biophysical components of the farm (e.g. crops, livestock, soils). Yet, especially for the livestock component, methods to quantify these effects for heterogeneous African farming systems are only now being described and tested (Rodriguez et al., 2017).

Livestock are affected by climate change through changes in feed resources, including their quantity, quality and temporal and spatial distribution, changes in temperature (heat stress), changes in the availability and quality of water resources and changes in disease occurrence and pressure (Thornton et al., 2009; Godber and Wall, 2014). In mixed smallholder farming systems, feed resources include grazed biomass from rangelands, crop residues and, to a lesser extent, forages and concentrates (Valbuena et al., 2015). Each of these feed resources may be affected by climate change in different ways. Smallholders usually keep livestock for multiple purposes, including functions for which herd size matters more than individual animal productivity, such as insurance, banking, socio-cultural and cropsupporting (manure, traction) functions (Moll, 2005; Mekonnen et al., 2011). As such, excessively large herd sizes often compromise the efficiency of milk and meat production. The different functions of livestock might be affected differentially by climate change and adaptation options, but also here, little is known about these impacts.

Semi-arid Zimbabwe was chosen as a case study, as it is representative for large areas of semi-arid land in southern Africa where rainfed agricultural production is the mainstay of the rural population but increasingly under threat from climate change (Masikati et al., 2015). Southern Africa is expected to be strongly exposed to the adverse effects of climate change, with a predicted temperature increase by the end of the century of up to $3-6{ }^{\circ} \mathrm{C}$, combined with likely less and more variable rainfall (Niang et al., 2014). The reliable crop growing days in the study area are expected to drop below 90 by the year 2050 (Jones and Thornton, 2009). In such conditions, it is expected that rainfed crop production will become increasingly risky and farmers will shift to livestock keeping. This trend is likely to be reinforced by the increasing demand for livestock products in the region (OECD/FAO, 2016). However, notwithstanding the importance of the sector, livestock has received very little attention in regional policy documents aimed at climate adaptation (van Garderen, 2011).

In this paper we present and use a modelling framework for assessing impacts on the livestock component of mixed systems in heterogeneous farm populations. We start with describing the farming system in the study area, and in particular the intake of different feed types over time. We then assess the impact of climate change and of two adaptation packages on the feedbase and on livestock production, while taking into account the uncertainty associated with different climate scenarios. In doing so, we test the hypothesis that different types of farms are affected differently by climate change and also by improved management. We further investigate whether the improved system is less sensitive to climate change than the current system.

\section{Materials and methods}

\subsection{Study area}

The rural district of Nkayi in Natural Region IV of Zimbabwe was chosen as a representative study area for semi-arid areas that cover about a third of Zimbabwe (Homann-Kee Tui et al., 2013b). The average annual rainfall in Nkayi is $650 \mathrm{~mm}$ with high interannual variability, and minimum and maximum mean temperatures are $15{ }^{\circ} \mathrm{C}$ and $30{ }^{\circ} \mathrm{C}$ respectively. With $>76 \%$ of the rural population below the poverty line (ZimVAC, 2013) and food self-sufficiency varying from 3 to 10 months depending on rainfall, rural households are extremely vulnerable to the adverse effects of climate change. Low and variable rainfall, combined with poor soil fertility and limited input use result in low agricultural productivity (Homann-Kee Tui et al., 2013b). Farming systems in Nkayi are mixed crop-livestock systems (Homann-Kee Tui et al., 2015a), in which crop residues are used as dry season feed, and livestock provides draft power and manure to crop production. All farmers cultivate maize (Zea mays L.), whereas about a third grows sorghum (Sorghum bicolor (L.) Moench) and pearl millet (Pennisetum glaucum (L.) R.Br.) and a third includes groundnut (Arachis hypogaea L.). Current crop yields are low, with maize yielding on average $0.7 \mathrm{tha}^{-1}$ and millet and groundnut not surpassing $0.5 \mathrm{tha}^{-1}$. About $60 \%$ of the households keep cattle and/or goats and donkeys, but productivity is also poor (Homann-Kee Tui et al., 2015a). Communal rangelands provide the major part of the livestock feedbase (HomannKee Tui et al., 2013b).

\subsection{Modelling framework and data}

We followed the Agricultural Model Intercomparison and Improvement Project (AgMIP) Regional Integrated Assessment (RIA) approach that links climate, crop, livestock and economic data and models for assessing the effect of climate change and adaptation options on heterogeneous farm populations (AgMIP, 2015). In this paper, we focused on the livestock component, and its links with the crop and rangeland components of the farming system. In our modelling framework (Fig. 1), field-level information on crop yields, community-level information on rangeland biomass, and herd-level information on animals is integrated with farm-level information on cropland allocation and soil, crop and livestock management practices. We assessed effects of climate change and two adaptation packages on feed availability and, through the feed, on various livestock outputs for all cattle-keeping households in a farm population. The AgMIP RIA models were calibrated for current production systems and run for the current and mid-century period (2040-2070). A detailed description of the methodology for the separate models can be found in the AgMIP RIA handbook (AgMIP, 2015), Antle et al. (2015) and Masikati et al. (2015). In what follows, we provide more details on the livestock model LIVSIM and the data and models feeding into LIVSIM.

\subsubsection{Household information}

Village and household data were collected in 2011 from 8 villages and a total of 160 households using individual interviews and group discussions. The sampling and interview methods are described in Homann-Kee Tui et al. (2013a). Farm households were stratified into three types (the extremely poor, poor and non-poor) based on resource endowments (Masikati et al., 2015). The modelling framework was run with specific settings for each household. Household-specific information on soil types, fertilizer rates and sowing windows were used in the crop growth model APSIM to simulate grain and stover yields of the major crops (see section 2.2.3). In combination with cropland areas, stover and forage yields were used to calculate farm-level feed availability for use in LIVSIM. Community-level information on rangeland areas and number of animals allowed estimating the rangeland stocking rate, which was used in combination with the grass simula- 


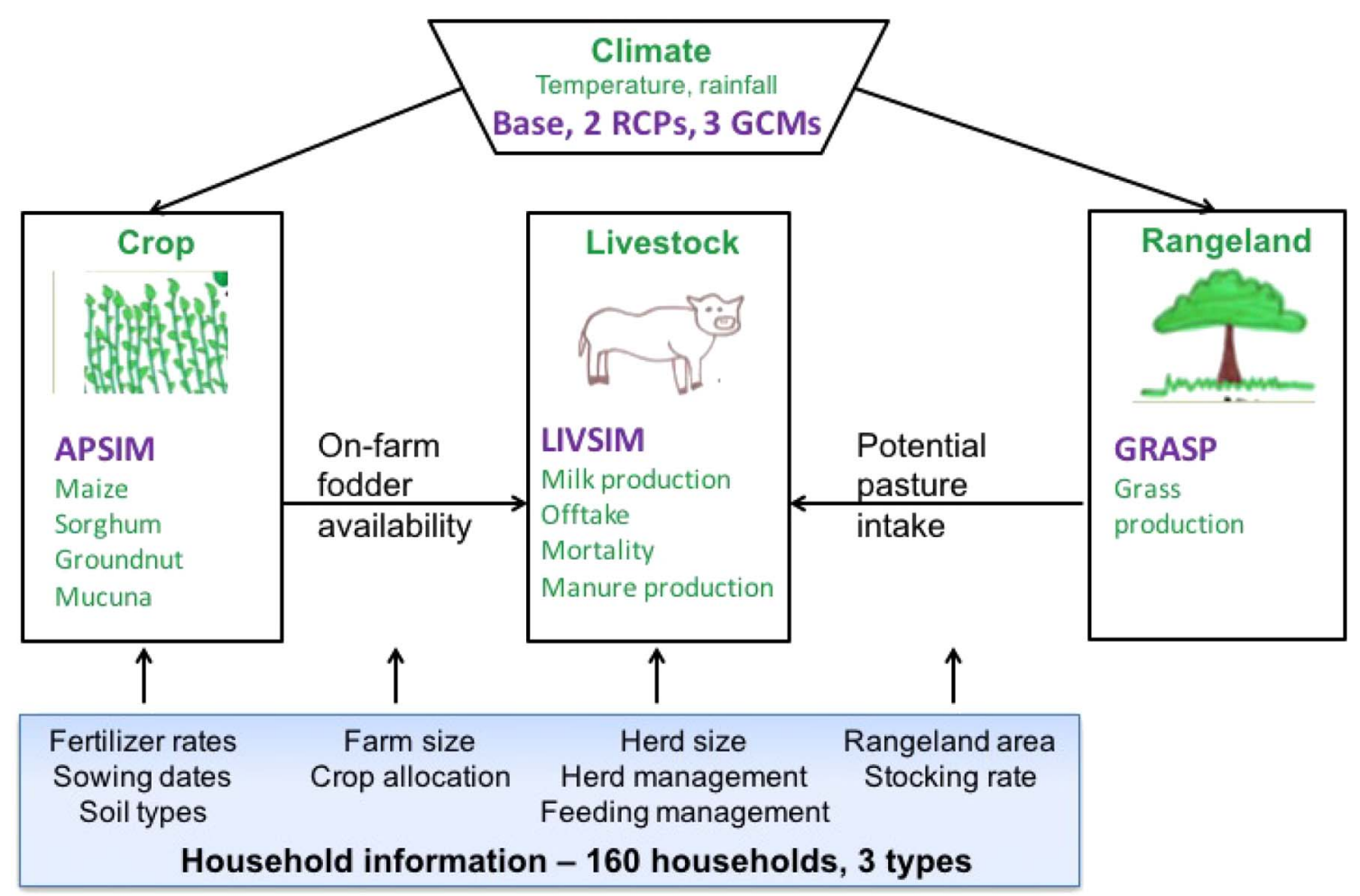

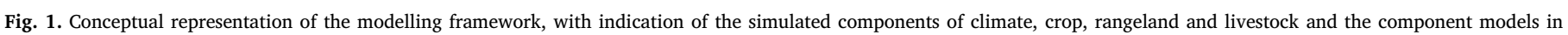
capitals. Arrows indicate information flows.

tions to derive the potential pasture intake (see section 2.2.4). Finally, data on livestock and feed management, herd size and composition were used to set up LIVSIM for each cattle-owning household in the database.

\subsubsection{Climate}

Continuous daily climate data sets of 31 years were produced for a baseline and multiple futures following Ruane et al. (2015). Sets consisted of daily minimum and maximum temperatures, rainfall and solar radiation. The baseline (1980-2010) was built from the best available daily observations for Nkayi district, filled where necessary with the AgMERRA data set. For the future data sets, two representative concentration pathways (RCP), RCP4.5 and RCP8.5, were used. The future climate data sets for the mid-century period (2040-2070) were generated by perturbing the baseline set until monthly mean and deviation distributions best fitted the distributions computed with 29 GCMs (Ruane et al., 2015), representing the best part of the CMIP5 experiments at the time (Taylor et al., 2012).

The future projections consistently showed increases in temperature. Rainfall projections were variable across GCMs, but suggested a consistent decrease during the rain onset in October and November. In this study three GCMs were selected as representatives of a cluster of most detrimental scenarios (labelled "hot-dry"), least detrimental scenarios ("cool-wet") and median scenarios ("middle") (Ruane and McDermid, 2017). The "hot-dry" scenarios suggested daily mean temperature changes ranging from $+2{ }^{\circ} \mathrm{C}$ to $+2.8{ }^{\circ} \mathrm{C}$ and $+2.7{ }^{\circ} \mathrm{C}$ to $+3.6{ }^{\circ} \mathrm{C}$ and daily rainfall changes ranging from $-2 \%$ to $-20 \%$, and $-5 \%$ to $-30 \%$ under RCP4.5 and RCP8.5 respectively. In the "coolwet" scenarios temperature changed by $+1{ }^{\circ} \mathrm{C}$ to $+2{ }^{\circ} \mathrm{C}$ and $+1.5^{\circ} \mathrm{C}$ to $+2.7{ }^{\circ} \mathrm{C}$ under RCP4.5 and RCP8.5, and daily rainfall changed by $-2 \%$ to $+12 \%$ under RCP 4.5 , and $-5 \%$ to $+22 \%$ under RCP8.5. The "middle" scenarios predicted daily mean temperature changes of $+1.7{ }^{\circ} \mathrm{C}$ to $+2.2{ }^{\circ} \mathrm{C}$ and $+2.5{ }^{\circ} \mathrm{C}$ to $+3{ }^{\circ} \mathrm{C}$, as well as daily rainfall changes of $-7 \%$ to $+3 \%$ and $-10 \%$ to $+1 \%$ under RCP4.5 and RCP8.5 respectively.

\subsubsection{Crop production}

Grain and stover yields of maize, sorghum, groundnut and the fodder crop mucuna (Mucuna pruriens (L.) DC.) were simulated using the Agricultural Production Systems Simulator model (APSIM; Holzworth et al., 2014). Crop and soil data from previous experiments in the same region were used to calibrate and evaluate the model (Masikati et al., 2013). APSIM was run for all crops, all households and for each 31-year climate scenario. Household-specific settings were used for soil type, fertilizer rate and sowing window. Three common soil types in the area, further referred to as good, medium and poor soils, were inherently infertile Kalahari sands, differing in their organic carbon content and plant available water capacity (soil descriptions in Masikati (2011) and Masikati et al. (2015)).

\subsubsection{Rangeland production and biomass availability}

Grass production in the rangelands was simulated with the pasture module GRASP (McKeon et al., 2000; Rickert et al., 2000) implemented in APSIM. GRASP was used previously for assessing effects of climate change in a wide range of rangeland and pasture environments in Australia (McKeon et al., 2009). GRASP was run for the typical "medium" soil of the study region (Masikati, 2011) with a topsoil $(0-15 \mathrm{~cm})$ organic carbon content of $0.5 \%$ and plant available water content of $72 \mathrm{~mm}$ in the top one meter. The same 31-year climate data as for the crop simulations were used. The $\mathrm{CO}_{2}$ fertilization effects were mimicked by adjusted GRASP parameters following Stokes et al. (2012). Model predictions were checked with literature values. As no detailed data on woody rangeland vegetation was available, we did not simulate browse biomass production, but estimated browse intake as explained below.

The monthly available grass biomass from the rangelands was calculated based on the simulated daily growth rate, averaged for every month. In our approach, the available biomass per animal depends strongly on the stocking rate, which was estimated at $2 \mathrm{ha} \mathrm{TLU}^{-1}$, midway the reported range of 0.5 to $3.5 \mathrm{ha} \mathrm{TLU}^{-1}$ (Masikati, 2011; Homann-Kee Tui et al., 2013b), and not on rangeland 
Table 1

Selected feed quality parameters in LIVSIM for the major feed resources in Nkayi district

Sources: Masikati, 2011; SSA feeds database (https://vslp.org/ssafeed/, last visited 29 October 2016).

\begin{tabular}{|c|c|c|c|c|c|}
\hline Feed resource & Parameter & Unit & $\begin{array}{l}\text { Rainy season } \\
\text { November-March }\end{array}$ & $\begin{array}{l}\text { Early dry season } \\
\text { April-June }\end{array}$ & $\begin{array}{l}\text { Late dry season } \\
\text { July-October }\end{array}$ \\
\hline \multirow[t]{6}{*}{ Grass } & Dry matter content & $\mathrm{g} \mathrm{kg}^{-1}$ & 200 & 500 & 800 \\
\hline & Metabolizable energy & $\mathrm{MJ} \mathrm{kg}^{-1}$ & 10.3 & 8.7 & 6.5 \\
\hline & Crude protein & $\mathrm{g} \mathrm{kg}^{-1}$ & 134 & 100 & 40 \\
\hline & Dry matter digestibility & $\mathrm{g} \mathrm{g}^{-1}$ & 0.65 & 0.48 & 0.48 \\
\hline & & & Fresh residue season & Old residue season & \\
\hline & & & March-September & October-February & \\
\hline \multirow[t]{4}{*}{ Maize stover } & Dry matter content & $\mathrm{g} \mathrm{kg}^{-1}$ & 910 & 910 & \\
\hline & Metabolizable energy & $\mathrm{MJ} \mathrm{kg}^{-1}$ & 8.7 & 7.6 & \\
\hline & Crude protein & $\mathrm{g} \mathrm{kg}^{-1}$ & 45 & 40 & \\
\hline & Dry matter digestibility & $\mathrm{g} \mathrm{g}^{-1}$ & 0.58 & 0.5 & \\
\hline \multirow[t]{4}{*}{ Sorghum stover } & Dry matter content & $\mathrm{g} \mathrm{kg}^{-1}$ & 910 & 910 & \\
\hline & Metabolizable energy & $\mathrm{MJ} \mathrm{kg}^{-1}$ & 8.4 & 7.4 & \\
\hline & Crude protein & $\mathrm{g} \mathrm{kg}^{-1}$ & 63 & 56 & \\
\hline & Dry matter digestibility & $\operatorname{g~g~}^{-1}$ & 0.63 & 0.55 & \\
\hline \multirow[t]{4}{*}{ Groundnut haulms } & Dry matter content & $\mathrm{g} \mathrm{kg}^{-1}$ & 920 & 920 & \\
\hline & Metabolizable energy & MJ kg ${ }^{-1}$ & 8.9 & 8.9 & \\
\hline & Crude protein & $\mathrm{g} \mathrm{kg}^{-1}$ & 145 & 145 & \\
\hline & Dry matter digestibility & $\mathrm{g} \mathrm{g}^{-1}$ & 0.6 & 0.6 & \\
\hline \multirow[t]{4}{*}{ Mucuna haulms } & Dry matter content & $\mathrm{g} \mathrm{kg}^{-1}$ & 920 & 920 & \\
\hline & Metabolizable energy & $\mathrm{MJ} \mathrm{kg}^{-1}$ & 9.5 & 9.5 & \\
\hline & Crude protein & $\mathrm{g} \mathrm{kg}^{-1}$ & 150 & 150 & \\
\hline & Dry matter digestibility & $\mathrm{g} \mathrm{g}^{-1}$ & 0.65 & 0.65 & \\
\hline
\end{tabular}

accessibility as in de Haan et al. (2016). A monthly loss rate of $20 \%$ was adopted to take account of senescence, trampling and a non-utilized fraction of the grass biomass. When available grass biomass provided less than the required dry matter (DM), $20 \%$ of the requirement was assumed to be met from browsing. This was based on reports from similar environments in Zimbabwe stating that cattle spend about 10 to $30 \%$ of their time browsing in the dry season (Scoones, 1995; Illius et al., 2000). The monthly DM requirement was derived from metabolizable energy (ME) requirements ranging from 45 to $65 \mathrm{MJ} \mathrm{ME} \mathrm{day}{ }^{-1}$ animal $^{-1}$ and grass ME content ranging from 6.5 to $10.3 \mathrm{MJ} \mathrm{kg}^{-1} \mathrm{DM}$ in the dry and the wet season respectively (Table 1 ).

\subsubsection{Livestock production}

In this study we focused on cattle and ignored other livestock species. Cattle production for each household in the database was simulated with the LIVSIM model (LIVestock SIMulator, Rufino et al., 2009), using the 31-year simulation results from the crop and rangeland models as input. Using a monthly time step, LIVSIM calculates the performance of every individual animal in the herd according to genetic potential, feed availability and quality, and herd management. Outputs comprise milk and manure production, body weight and herd dynamics, including offtake and mortality. LIVSIM was previously tested for Zimbabwean conditions with data from feeding trials with the Mashona breed (Rufino et al., 2011). For this study, LIVSIM was run for a local breed showing characteristics of the Nkone and Tuli breeds and their mixes. Breed characteristics, collected from literature (Garwe, 2001; Ngongoni et al., 2006; DAGRIS, 2007) and secondary data, were used for parameter derivation (Fig. 2, Table 2). Typical herd composition, herd and feeding management parameters were set based on expert knowledge and information derived from the household survey (Table 2). For example, in the model we specified that rangeland grazing takes place throughout the year, that crop residues are fed from June to December and that $80 \%$ of the stover is available for animal feeding. We further assumed that crop residues were fed exclusively to the animals of a particular farm.

Formal model validation requires data from feeding trials on feed intake in conjunction with for example data on milk production and body weight. For the local breed and feed resources in Nkayi no such data was available. Hence, "model sensibility" was tested by comparing

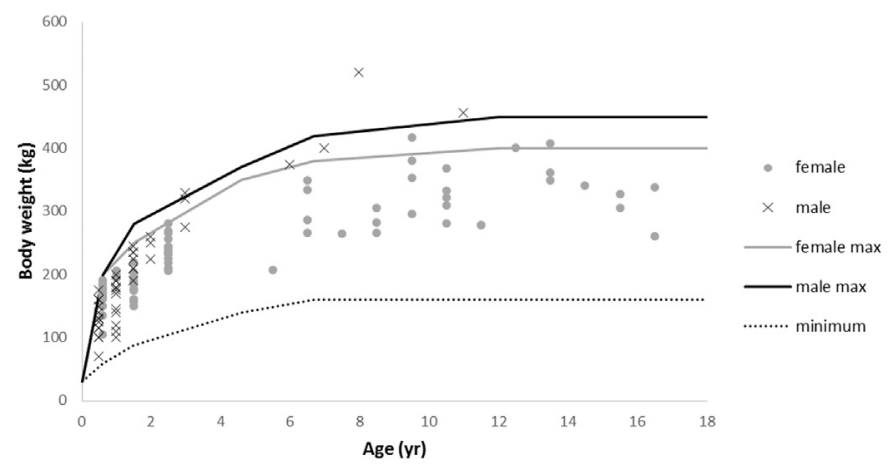

Fig. 2. Potential growth and minimum body weight curves for the local Nkone and Tuli breeds, as used in the LIVSIM model runs, with scatter points indicating measured body weight and age.

(Data source: Matopos research station)

Table 2

LIVSIM breed and livestock management parameters for the farming system in Nkayi district.

Sources: Garwe (2001); Ngongoni et al. (2006); DAGRIS (2007).

\begin{tabular}{|c|c|c|}
\hline Parameter & Unit & Value \\
\hline Maximum lactation length & months & 10 \\
\hline $\begin{array}{l}\text { Potential milk yield over the } \\
\text { duration of one lactation }\end{array}$ & $\mathrm{kg}_{\text {year }}{ }^{-1}$ & $\begin{array}{l}\text { linear interpolation between } 200 \text {, } \\
1100,0 \text { in month } 0,2 \text { and } 10 \text { resp. }\end{array}$ \\
\hline $\begin{array}{l}\text { Milk fat content throughout } \\
\text { lactation }\end{array}$ & $\mathrm{g} \mathrm{kg}^{-1}$ & $\begin{array}{l}\text { linear interpolation between } 27 \text {, } \\
32,37,40 \text { in month } 0,3,6,10 \\
\text { resp. }\end{array}$ \\
\hline Milk dry matter content & $\mathrm{g} \mathrm{kg}^{-1}$ & 130 \\
\hline Milk energy content & $\mathrm{MJ} \mathrm{kg}^{-1}$ & 19.6 \\
\hline Milk crude protein content & $\%$ & 3.2 \\
\hline Weaning age & year & 1.4 \\
\hline Daily walking distance & $\mathrm{km}$ & 6.0 \\
\hline $\begin{array}{l}\text { Maximum number of } \\
\text { lactations }^{\mathrm{a}}\end{array}$ & $\#$ & 4.0 \\
\hline Maximum "dry" period" ${ }^{a}$ & year & 3.0 \\
\hline
\end{tabular}

a Before the animal is replaced. 
model outputs with farmer-reported livestock production from the household survey. In addition, a sensitivity analysis was performed on major feed and animal parameters and input variables, including productivity, metabolizable energy and crude protein content of crop residues and grass, milk yield potential, length of lactation, minimum and maximum body weight, daily walking distance, maximum number of lactations and maximum "dry" period before culling. Each parameter was varied from $-50 \%$ to $+50 \%$ of its original value with steps of $10 \%$, while keeping the other parameters constant. The model was run with one animal and three farm stocking densities (2, 4 and $8 \mathrm{TLU} \mathrm{ha}^{-1}$ ). For each parameter and stocking density, a sensitivity index (SI) was calculated based on the lifetime milk production (M, $\mathrm{kg}$ cow $^{-1}$ ) of the cow:

$S I=\frac{M_{+0.5}-M_{-0.5}}{M_{0}}$

where $\mathrm{M}_{+0.5}, \mathrm{M}_{-0.5}$, and $\mathrm{M}_{0}$ refer to the lifetime milk production for parameter values that deviate $+50 \%,-50 \%$ and $0 \%$ from the original value respectively.

\subsubsection{Scenario analysis}

The modelling framework was run for each combination of seven climate scenarios (baseline and six future climates) and two management scenarios (current and improved) to assess the sensitivity to climate change and effects of adaptation. The current system was based on crop and livestock management information derived from the survey. For the improved system, effects of altered management were evaluated by comparing two adaptation packages ( $a$ and b). "Package a" consisted of improved soil fertility management with mineral fertilizer $\left(20 \mathrm{~kg} \mathrm{~N} \mathrm{ha}^{-1}\right)$ and manure $\left(1 \mathrm{tha}^{-1}\right)$ on both maize and sorghum. "Package b" combined the former with the inclusion of grain and fodder legumes in rotation with the cereals. A minimum area of maize was kept to secure food self-sufficiency and the rest of the maize area was converted equally into groundnut and mucuna, resulting in new farm-specific cropland allocations. Mucuna biomass was used both as fodder $(70 \%)$ and as mulch (30\%), contributing to soil fertility. For all scenarios, simulated values of milk, manure, herd size, mortality and offtake were assessed for all households. A simple analysis of costs and benefits, following the procedures of Homann-Kee Tui et al. (2015a) and using local prices at the time of the survey, allowed calculating annual net revenues from the simulated livestock outputs of milk, offtake, draft power, and manure.

\section{Results}

\subsection{Household characteristics}

From the household database comprising 160 households, we omitted the extremely poor that do not own cattle ( $43 \%$ of the farm population). Average herd sizes for the remaining 91 households were 5.4 and $13.6 \mathrm{TLU}$ for the poor (38\% of the population) and non-poor households (19\% of the population) respectively (Table 3). Cropland area and stocking density were significantly larger for non-poor farmers, compared to poor farmers. Herd composition, cropland allocation to the major crops and the proportions of farmers growing maize, sorghum and groundnut were similar for both groups (Table 3 ). Within the farm types there was still considerable variation in farm structural characteristics. For example, the stocking density ranged from 0.2 to 18.2 $\mathrm{TLU} \mathrm{ha}^{-1}$ and from 1.7 to $38 \mathrm{TLU} \mathrm{ha}^{-1}$ in the poor and non-poor group respectively. As the farm stocking density determines fodder availability, thereby influencing livestock productivity, further analyses were differentiated by stocking density class (Table 3 ).

\subsection{Model evaluation}

The performance of the APSIM model was evaluated elsewhere
Table 3

Crop and livestock herd characteristics (averages with standard deviation in brackets) of poor and non-poor farm households in the Nkayi district.

\begin{tabular}{|c|c|c|}
\hline & Poor & Non-poor \\
\hline Number of households & 61 & 30 \\
\hline Cropland area (ha) & $2.0(1.3)$ & $2.7(1.7)$ \\
\hline$\%$ farmers growing maize & 100 & 100 \\
\hline Cropland allocation to maize (\%) & $77(22)$ & $72(23)$ \\
\hline$\%$ farmers growing sorghum & 33 & 43 \\
\hline Cropland allocation to sorghum (\%) & $9(16)$ & $14(22)$ \\
\hline$\%$ farmers growing groundnut & 49 & 47 \\
\hline Cropland allocation to groundnut (\%) & $10(13)$ & $11(15)$ \\
\hline Total cattle TLU & $5.4(2.5)$ & $13.6(4.0)$ \\
\hline Number of adult female cattle & $1.7(1.0)$ & $4.5(2.0)$ \\
\hline Number of adult male cattle & $1.1(1.1)$ & $2.1(1.5)$ \\
\hline Number of heifers and young steers & $1.1(1.1)$ & $3.4(1.7)$ \\
\hline Number of calves & $0.7(0.9)$ & $2.2(1.7)$ \\
\hline Stocking rate (TLU ha ${ }^{-1}$ ) & $3.7(3.0)$ & $8.5(8.3)$ \\
\hline Stocking density (SD) classes & $\begin{array}{l}\text { Number of } \\
\text { households }\end{array}$ & $\begin{array}{l}\text { Number of } \\
\text { households }\end{array}$ \\
\hline SD2: $\mathrm{SD}<2.5 \mathrm{TLU} \mathrm{ha}^{-1}$ & 24 & 4 \\
\hline SD4: $\mathrm{SD} \geq 2.5$ and $\mathrm{SD}<5 \mathrm{TLU}^{-1}$ & 23 & 8 \\
\hline SD8: SD $\geq 5 \mathrm{TLU} \mathrm{ha}^{-1}$ & 14 & 18 \\
\hline
\end{tabular}

(Masikati et al., 2013, 2015). Average simulated grass production in the rangelands was $1358 \mathrm{~kg} \mathrm{ha}^{-1}$ (ranging from 542 to $2199 \mathrm{~kg} \mathrm{ha}^{-1}$ ) for the baseline climate. The simulations corresponded with general productivity values for savanna vegetation (Rutherford, 1978) and with specific data from areas similar to the study site. For example, depending on the utilization rate, mean annual production for semi-arid bush savanna in South-East Zimbabwe ranged from 1217 to $2084 \mathrm{~kg} \mathrm{ha}^{-1}$ for sites with annual rainfall of 520-620 mm (Kelly and Walker, 1976). Depending on soil texture and rainfall, grass production varied from $150-500 \mathrm{~kg} \mathrm{ha}^{-1}$ to $700-2166 \mathrm{~kg} \mathrm{ha}^{-1}$ (Scoones, 1995), in line with values of 683 to $2194 \mathrm{~kg} \mathrm{ha}^{-1}$ for Natural Region IV of Zimbabwe (Dye and Spear, 1982) and with $1046 \mathrm{~kg} \mathrm{ha}^{-1}$ for nearby Matopos (Masikati, 2011). We found a slope of 2.2 for the regression $\left(\mathrm{R}^{2}=0.66, \mathrm{p}<0.001\right)$ between seasonal rainfall and simulated biomass production, which is within the range of slopes of 1.3 for a less fertile Matopos Sandveld and 3.6 for a more fertile Matopos Thornveld (Dye and Spear, 1982), indicating that the effect of rainfall on grass production was adequately captured by the model.

Annual simulated milk production per farm $\left(923 \mathrm{~kg} \mathrm{yr}^{-1}\right.$ on average across all households) was larger than the reported values (584 $\mathrm{kg} \mathrm{yr}^{-1}$ on average) (Fig. 3a). Whereas the variability for the simulated data $(\mathrm{CV}=0.48)$ was lower than for the observed data $(\mathrm{CV}=0.89)$, the model captured the trend in the observed data with an $\mathrm{R}^{2}$ of 0.53 (Fig. 3a). The simulation also overestimated the reported number of calves with an average calving rate of 0.36 against 0.20 for the reported values. Nevertheless, the $\mathrm{R}^{2}$ value of 0.63 showed that the model captured a large part of the variability in the reported numbers (Fig. 3b). The average simulated cattle mortality rate (3\%) was smaller than the average reported rate of $14 \%$.

Although LIVSIM overestimated livestock production compared to the farmer-reported values, several factors call for a cautious interpretation. Firstly, the survey data were based on farmer recall, which is dubious as farmers typically do not measure animal production, use standard measuring devices, or keep records. Secondly, smallholders are often reluctant to disclose information about their animals, which are a wealth indicator. Thirdly, the LIVSIM model does not take into account animal losses due to disease, theft, or other stochastic factors. Nevertheless, LIVSIM captured the overall trend in reported values and the variability between households reasonably well.

The sensitivity analysis revealed that livestock productivity was less 


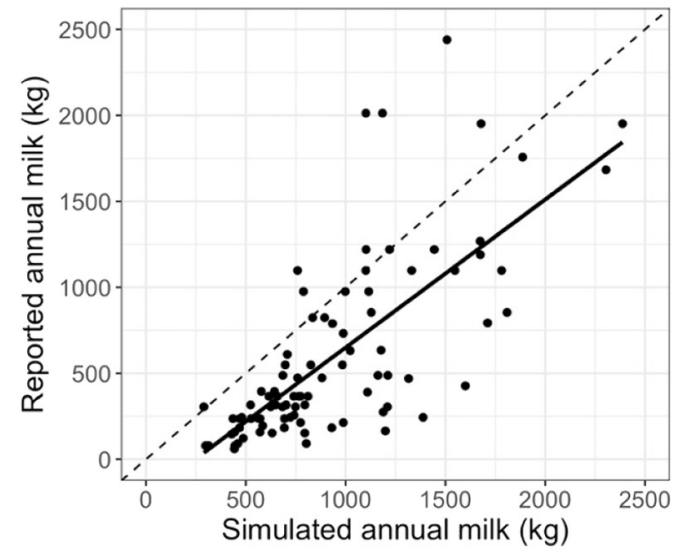

(a)

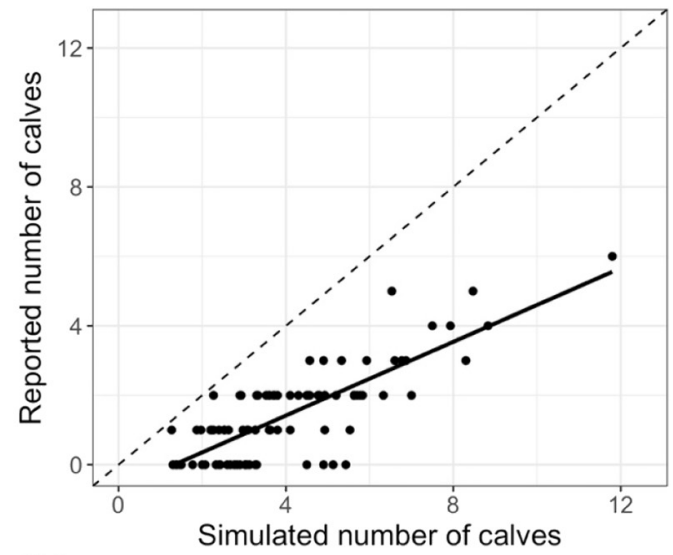

(b)

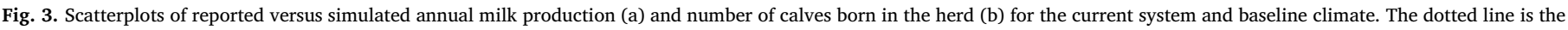
1:1 line and the full line is the regression line.

affected by changes in crop residue than in pasture parameters (Fig. 4), because of the larger contribution of pasture to the annual diet (Fig. 5). Similarly, pasture productivity was more determining for farms with larger stocking density. With respect to the breed-related parameters, the model was sensitive mostly to the potential milk yield (Fig. 4). Minimum and maximum body weight also influenced lifetime milk production, which was largest between $-40 \%$ and $+10 \%$ of the original parameter values. Management parameters were generally less important. Overall, LIVSIM is reacting to changes in parameter and input variables as expected and the model is relatively robust when parameter values stay within a reasonable range of uncertainty.

\subsection{The livestock feedbase under baseline and future climate conditions}

During the rainy and early dry seasons, cattle depended on rangeland grazing, which was supplemented with on-farm fodder resources from June to December (Fig. 5). Crop residues provided a varying proportion of the livestock diet, decreasing from $40 \%$ to $10 \%$ with increasing stocking density. Cattle experienced feed gaps from August up to October, especially in terms of energy and protein supply and particularly on densely stocked farms (Fig. 5).

Climate change is expected to affect both the rangeland and the onfarm fodder production (Fig. 1). Average grass production in the rangelands decreased only in the "hot-dry" scenarios, particularly under RCP8.5 (Fig. 6). In the "middle" scenario grass production did not deviate much from the baseline production, whereas in the "coolwet" scenario, grass production improved. The year-to-year variability in grass production increased in all future climate scenarios: compared to the baseline (coefficient of variation (CV) 0.38), CVs increased by $20 \%$ in the "cool-wet" to $47 \%$ in the "hot-dry" scenarios of RCP8.5.

Average simulated stover yields ranged from 1.3 to $3.6 \mathrm{tha}^{-1}$ for maize and 1.4 to $1.9 \mathrm{tha}^{-1}$ for groundnut on poor to good soils

(a)

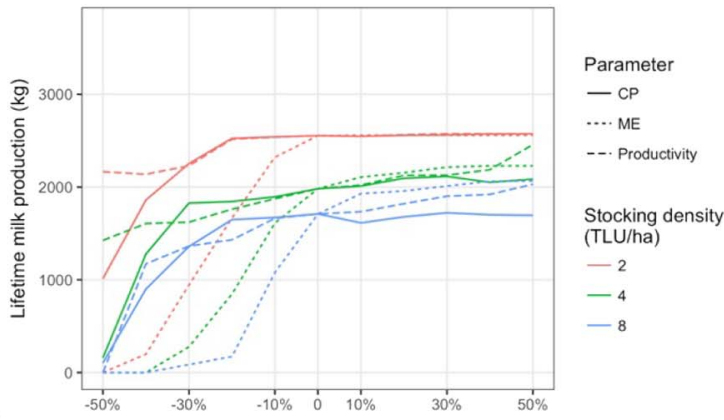

(b)
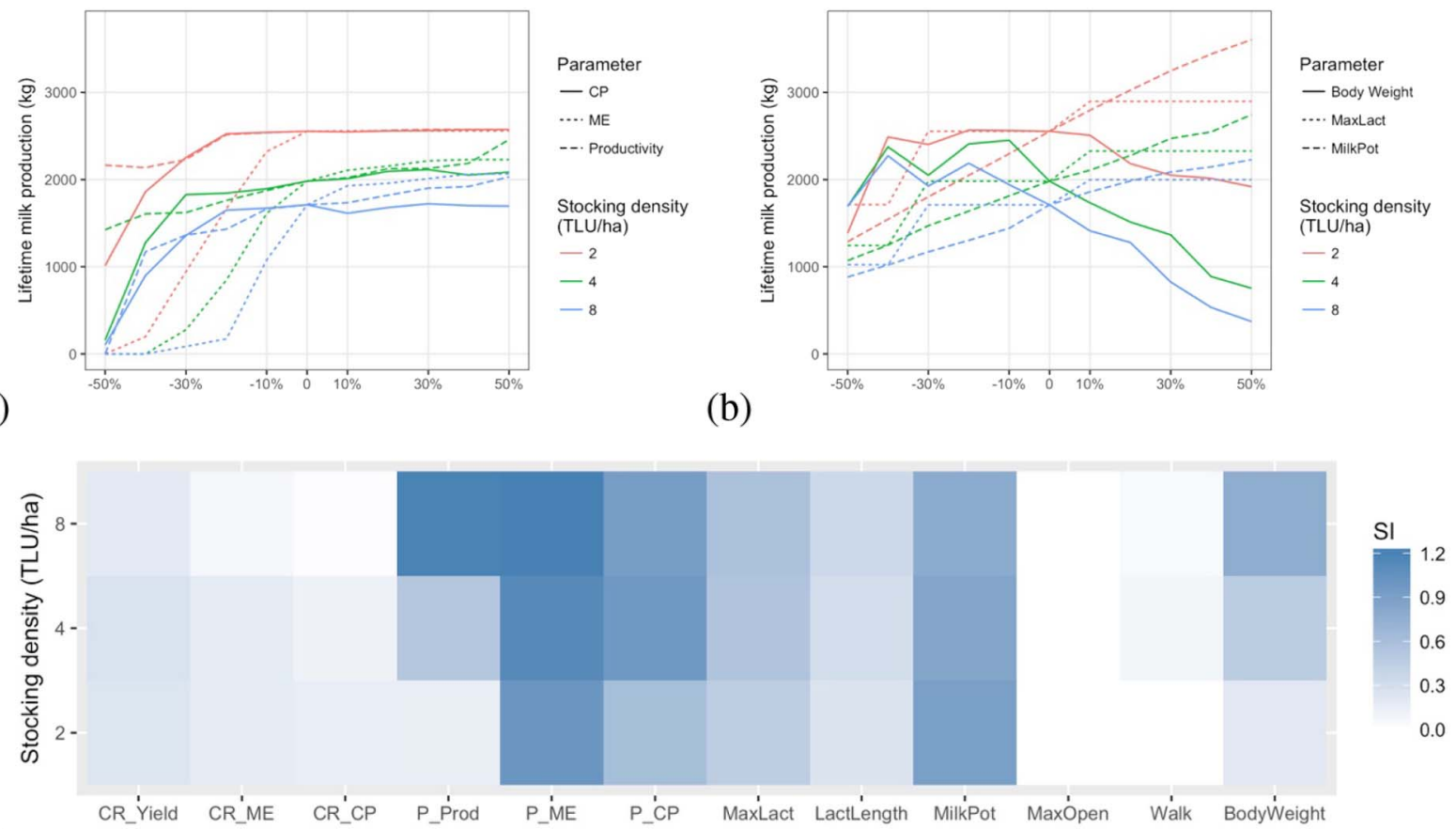

(c)

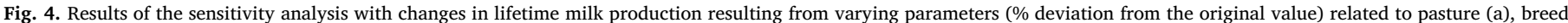

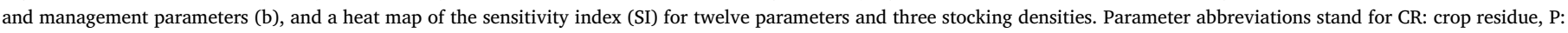

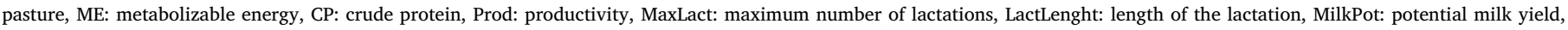
MaxOpen: maximum period open, Walk: daily walking distance, BodyWeight: minimum and maximum body weight. 

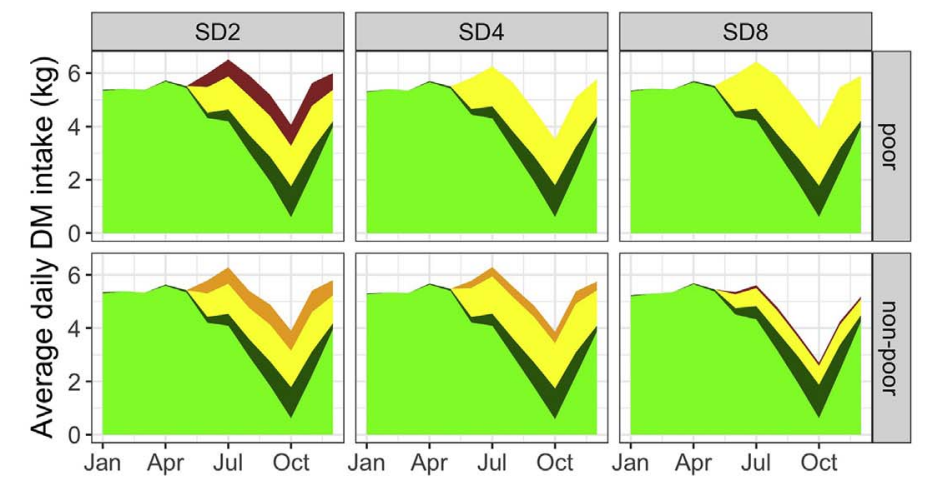

(a)
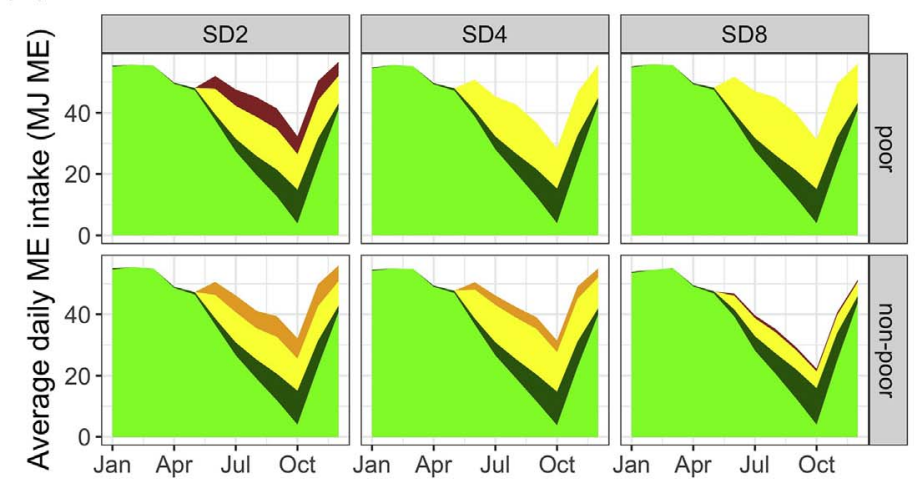

(b)
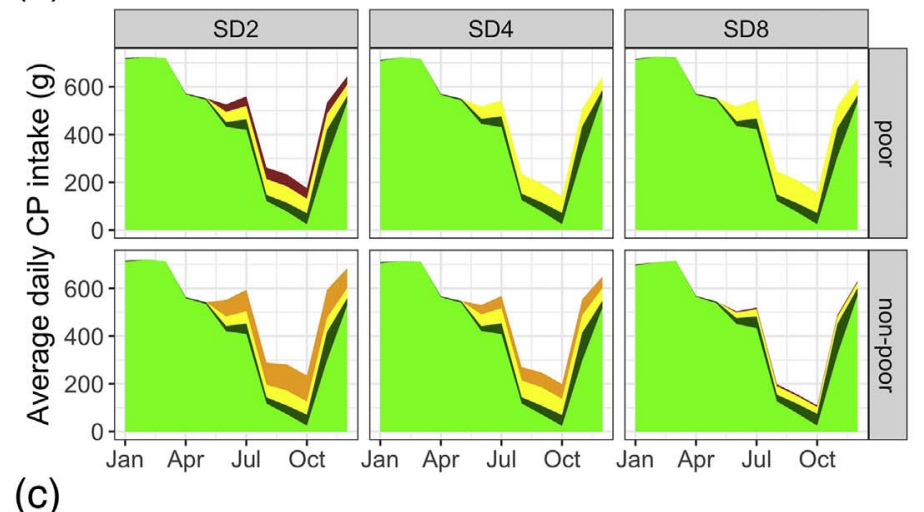

Groundnut

Sorghum

Maize

Browse

Grass

\section{Groundnut \\ Sorghum \\ Maize \\ Browse \\ Grass}

Groundnut

Sorghum

Maize

Browse

Grass

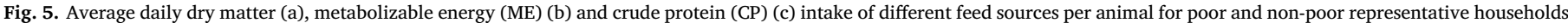

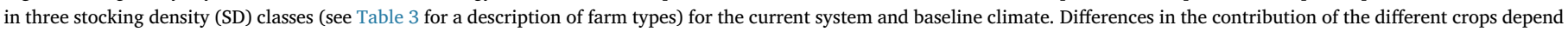
on the farm-specific cropland allocation. Crop names refer to crop residues.

respectively in the baseline climate (Table 4). Sorghum was only grown on poor soils and stover yielded $1.5 \mathrm{tha}^{-1}$. Climate change lowered average cereal stover yields by up to $5 \%$ and $12 \%$ for RCP4.5 and RCP8.5 respectively and most strongly in the "hot-dry" scenarios (Table 4). The year-to-year variability increased in the "hot-dry" scenarios, especially under RCP8.5, and decreased in the "cool-wet" scenarios. Average groundnut stover yield and its variability increased with climate change and more strongly with higher $\mathrm{CO}_{2}$ concentration, except for the "hot-dry" scenario (Table 4). As a result of changes in feed production, the average annual fodder intake per animal decreased in the "hot-dry" scenarios by up to $9 \%$ compared to the baseline, with a stronger decrease on farms with higher stocking density. Conversely, in the "cool-wet" scenario of RCP8.5 an increase in fodder intake of up to $5 \%$ was simulated.

\subsection{Livestock production under baseline and future climate conditions}

Simulated body weight varied strongly throughout the year, with cows losing weight in the dry season especially because of lack of protein in the feed, and gaining weight again in the wet season from plenty high quality fodder in the rangelands (Figs. 5 and 7, Table 1). Body weight fluctuations are a major cause of inefficiency, because the feed resources used to regain animal body condition after the dry season can not be used for production. Besides fluctuations within the year, livestock production also strongly varied between years. Coefficients of variation (CV) ranged between 0.4 and 0.6 for annual milk production, and 0.3 and 0.4 for net revenue in the baseline climate (Table 5), illustrating the riskiness of the livestock component in semiarid mixed systems. Outputs linked to animal numbers, such as manure, varied less between years (Table 5). Livestock production further varied with herd size, which positively influenced livestock outputs in absolute terms, and with stocking density, which adversely affected individual animal productivity (Table 5). Net revenue, aggregating all livestock outputs and services, was larger and less variable in non-poor households, because larger herds better maintained a steady flow of outputs. In the current system, simulated milk, offtake and draft power each 


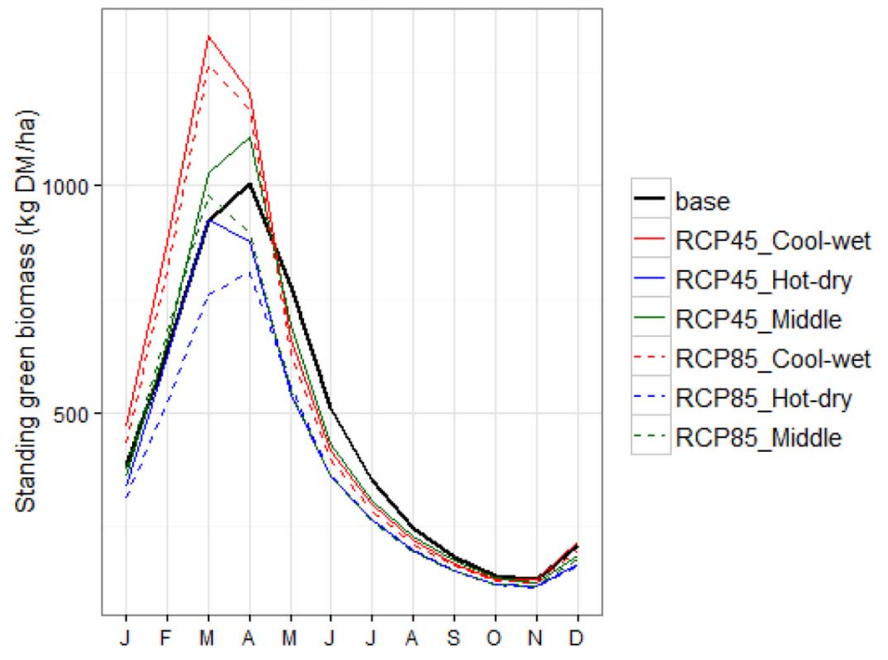

Fig. 6. Average simulated monthly grass biomass for different climate scenarios.

contributed about one third of the annual revenue, whereas manure contributed very little because of its current very limited use. Because annual net revenues were based on simulated livestock output values, they overestimated farmers' reported income from cattle, which was 485 and 1363 US\$ per year per farm for poor and non-poor farms respectively (Homann-Kee Tui et al., 2015a). Hence, in the following we pay more attention to relative changes than to absolute values.

Climate change had variable effects on simulated livestock production depending on the climate scenario and the farm characteristics. Livestock net revenues were negatively impacted in the "hot-dry" scenarios for nearly all farms with an average decrease compared to the baseline of 8 to $32 \%$ in RCP4.5 and 11 to $43 \%$ in RCP8.5. Households with larger stocking densities faced larger impacts (Fig. 8). Also the "middle" scenario of RCP8.5 resulted in a clear negative impact with relative declines in net revenue of 5-24\%. Both "cool-wet" scenarios and the "middle" scenario of RCP4.5 resulted in overall positive, but small changes. However, even in these most positive scenarios about $25-30 \%$ of the farm population faced negative impacts. The "hot-dry" scenarios most strongly increased the risk farmers are facing, with a relative increase in the CV of up to $143 \%$ for RCP8.5. Again, this increase in risk is more pronounced for farms with larger stocking density. Also for the individual livestock outputs, the most severe impacts were simulated with the "hot-dry" scenario, which also led to the largest risk of losing animals (Fig. 9). The other scenarios resulted in milder effects, but due to the heterogeneity in the farm population, considerable proportions of the farmers still faced negative impacts.

Livestock functions depending on animal productivity (e.g. milk production, offtake) were more strongly affected by climate change than functions depending primarily on animal numbers (e.g. manure, draft power). This was because a decrease in fodder availability

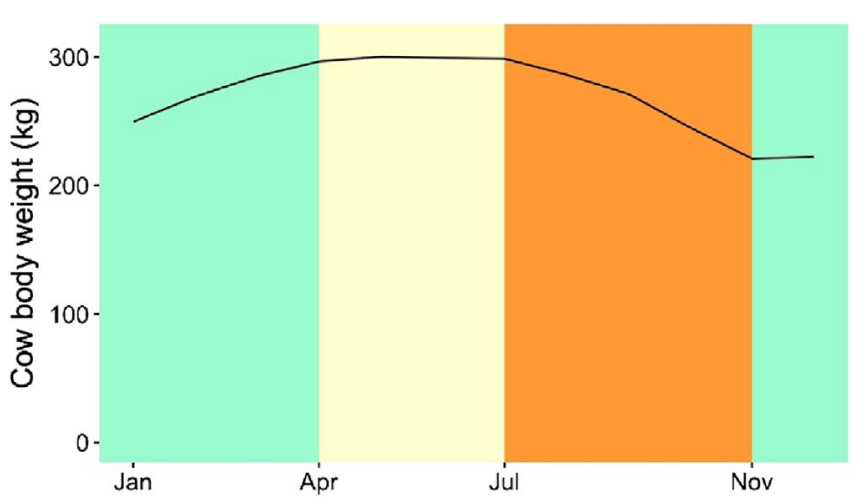

Fig. 7. Average simulated body weight evolution through the year for the current system and baseline climate. Colours indicate the seasons, with green the rainy season, yellow the early dry season and orange the late dry season. (For interpretation of the references to colour in this figure legend, the reader is referred to the web version of this article.)

immediately affected the energy and protein available for producing milk, gestation, and maintaining animal body condition. In contrast, the ability of animals to lose and re-gain weight cushioned the herd against changes in fodder availability. Across all livestock production indicators, stronger effects of climate change were simulated for the more densely stocked farms. Here, animals faced severe feed gaps in the dry season (Fig. 5), and any further drop in fodder production, further impaired their productivity, lowered their body condition and eventually increased mortality (Fig. 9).

\subsection{Effects of the adaptation packages}

The packages of intervention options improved the on-farm fodder production and quality. Compared to the current system, maize stover yields improved with "package a" by 27, 62 and $111 \%$ on good, medium and poor soils respectively because of organic and mineral fertilizer application. Thanks to additional rotational benefits in "package b", maize stover yields on good, medium and poor soils improved by 44, 112 and $201 \%$ compared to the baseline. As part of "package b", mucuna produced on average 4.3 to 5.0 t DM biomass per ha, depending on the soil type. Dry season feed gaps were weakly narrowed with "package a" and largely alleviated with "package b". Thanks to increased cereal stover production in "package a", total annual feed intake increased with 5\% compared to the current system (Fig. 10a). However, as cereal stover is of poor quality, energy and protein gaps in the dry season remained. With "package b", leguminous stover from groundnut and mucuna improved not only the dry matter intake, but also the intake of metabolizable energy by $7-14 \%$ and crude protein by $10-26 \%$ (Fig. 10b), depending on the farm type. Only the most densely stocked farms still experienced a drop in crude protein intake in the dry season (results not shown).

Improvements in the feedbase because of the adaptation package were translated in increased livestock production and net revenues.

Table 4

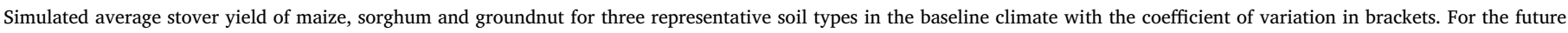
climate scenarios, average percentage change relative to the baseline yield and to the baseline coefficient of variation in brackets.

\begin{tabular}{|c|c|c|c|c|c|c|c|c|}
\hline \multirow[t]{2}{*}{ Crop } & \multirow[t]{2}{*}{ Soil class } & \multirow[t]{2}{*}{ Baseline stover yield $\left(\mathrm{kg} \mathrm{ha}^{-1}\right)$} & \multicolumn{3}{|l|}{$\mathrm{RCP} 4.5$} & \multicolumn{3}{|l|}{ RCP8.5 } \\
\hline & & & Cool-wet & Hot-dry & Middle & Cool-wet & Hot-dry & Middle \\
\hline \multirow[t]{3}{*}{ Maize } & Poor & $1349(0.08)$ & $-3(-20)$ & $-5(3)$ & $-5(0)$ & $-5(-17)$ & $-8(20)$ & $-1(0)$ \\
\hline & Medium & $2124(0.08)$ & $-2(-2)$ & $-5(18)$ & $-5(3)$ & $-3(-4)$ & $-9(50)$ & $-1(-3)$ \\
\hline & Good & $3611(0.14)$ & $0(-11)$ & $-5(17)$ & $-4(1)$ & $-1(-14)$ & $-12(53)$ & $-2(5)$ \\
\hline Sorghum & Poor & $1520(0.10)$ & $-2(-2)$ & $-6(1)$ & $-5(0)$ & $-3(-5)$ & $-7(12)$ & $-3(1)$ \\
\hline \multirow[t]{3}{*}{ Groundnut } & Poor & $1408(0.26)$ & $29(13)$ & $21(33)$ & 29 (15) & $36(12)$ & $15(53)$ & $32(25)$ \\
\hline & Medium & $1951(0.32)$ & $24(8)$ & $17(23)$ & $24(9)$ & $32(7)$ & 10 (39) & $28(17)$ \\
\hline & Good & $1895(0.28)$ & $19(6)$ & $12(24)$ & $17(9)$ & $27(6)$ & $6(41)$ & $23(20)$ \\
\hline
\end{tabular}


Table 5

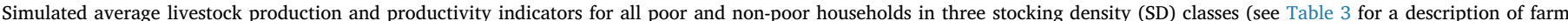

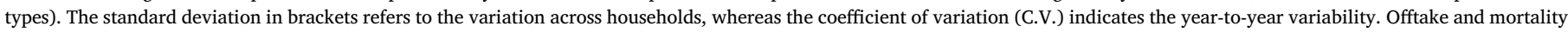
rate are calculated as the number of sold and dead animals in a year divided by the number of animals in the herd.

\begin{tabular}{|c|c|c|c|c|c|c|}
\hline \multirow[t]{2}{*}{ Indicator (unit) } & \multicolumn{3}{|l|}{ Poor } & \multicolumn{3}{|l|}{ Non-poor } \\
\hline & SD2 & SD4 & SD8 & SD2 & SD4 & SD8 \\
\hline Annual milk $\left(\mathrm{kg} \mathrm{farm}^{-1}\right)$ & $644(236)$ & $691(219)$ & $785(215)$ & $1377(231)$ & $1677(352)$ & 1265 (409) \\
\hline Annual milk C.V. $(-)$ & $0.48(0.08)$ & $0.53(0.09)$ & $0.54(0.06)$ & $0.42(0.03)$ & $0.46(0.04)$ & $0.57(0.07)$ \\
\hline Milk per lactation $\left(\mathrm{kg} \mathrm{cow}^{-1}\right)$ & $329(99)$ & $289(96)$ & $281(93)$ & $318(90)$ & $328(96)$ & $263(92)$ \\
\hline Annual offtake (sold animals) & $2.3(1.0)$ & $2.7(0.9)$ & $3.1(0.8)$ & $5.1(0.7)$ & $6.2(1.0)$ & $5.3(1.9)$ \\
\hline Annual offtake C.V. (-) & $0.57(0.13)$ & $0.61(0.15)$ & $0.58(0.10)$ & $0.39(0.04)$ & $0.41(0.08)$ & $0.56(0.11)$ \\
\hline Offtake rate $(-)$ & $0.28(0.05)$ & $0.29(0.04)$ & $0.30(0.04)$ & $0.35(0.02)$ & $0.36(0.03)$ & $0.32(0.04)$ \\
\hline Annual mortality (animals) & $0.16(0.10)$ & $0.28(0.07)$ & $0.38(0.16)$ & $0.32(0.08)$ & $0.34(0.21)$ & $0.66(0.25)$ \\
\hline Annual mortality C.V. (-) & $3.02(0.68)$ & $2.34(0.36)$ & $2.46(0.30)$ & $2.68(0.19)$ & $3.14(0.72)$ & $2.42(0.26)$ \\
\hline Mortality rate $(-)$ & $0.022(0.012)$ & $0.036(0.012)$ & $0.040(0.016)$ & $0.023(0.005)$ & $0.021(0.012)$ & $0.044(0.016)$ \\
\hline Annual manure $\left(\mathrm{kg} \mathrm{DM} \mathrm{farm}^{-1}\right)$ & $6154(1858)$ & $6856(1624)$ & $7539(1451)$ & 11,719 (1799) & $13,980(2487)$ & $11,969(3426)$ \\
\hline Annual manure C.V. $(-)$ & $0.24(0.06)$ & $0.23(0.04)$ & $0.22(0.02)$ & $0.16(0.02)$ & $0.17(0.02)$ & $0.22(0.04)$ \\
\hline Potential manure application rate $\left(\mathrm{kg} \mathrm{DM} \mathrm{ha}^{-1}\right)$ & 2919 (1033) & 4674 (1189) & $7445(2238)$ & $3253(1428)$ & 3935 (769) & $9668(5942)$ \\
\hline Annual net revenue (US\$) & $1759(652)$ & $1989(585)$ & $2267(544)$ & $3725(540)$ & $4487(785)$ & 3755 (1197) \\
\hline Annual net revenue C.V. $(-)$ & $0.36(0.06)$ & $0.38(0.07)$ & $0.37(0.04)$ & $0.29(0.02)$ & $0.30(0.04)$ & $0.39(0.07)$ \\
\hline Contribution to annual revenue (milk/offtake/draft/manure, \%) & $34 / 32 / 33 / 1$ & $32 / 33 / 34 / 1$ & $32 / 33 / 33 / 1$ & $35 / 34 / 30 / 1$ & $35 / 34 / 29 / 1$ & $32 / 34 / 33 / 1$ \\
\hline
\end{tabular}

Compared to the current system, average annual milk production increased slightly with "package a" up to $6 \%$, and more strongly up to $30 \%$ with "package b". Similarly the milk productivity of individual animals changed slightly with "package a", and more considerably by 15-30\% with "package b" (Fig. 11). For offtake rates, smaller improvements were observed up to $15 \%$. Aggregating all livestock outputs, net revenues increased by up to $12 \%$ and $20 \%$ compared to the current system with "package a" and "b" respectively (Fig. 8). In the improved system, year-to-year variation declined with the CV of net revenues up to $13 \%$ lower than in the current system. This decreased riskiness was also reflected in reduced chances of animal mortality (Fig. 9). The larger positive effect of "package b" compared to "package a" (Figs. 8 and 11) was attributed to the larger protein intake from leguminous stover, confirming that the current feed gaps are related more to feed quality than to feed quantity.

The negative effects of climate change on cereal crops were stronger in the improved system compared to the current system (results not shown). In the current system, soil nutrient limitations attenuated the potential adverse effects of temperature or drought stress, and this was less so in the improved system due to fertilizer and manure input. For livestock, the opposite was found with the improved system less sensitive to climate change, because the alleviation of feed gaps provided a buffer against drops in feed availability. For example in the "hot-dry" scenario the average decrease in net revenues amounted to $28 \%$ for the improved system instead of $43 \%$ for the current system. Whereas nearly all current farms faced declining net revenues with climate change, "package b" reduced this proportion to 60 and $76 \%$ of the farm population in RCP4.5 and RCP8.5.
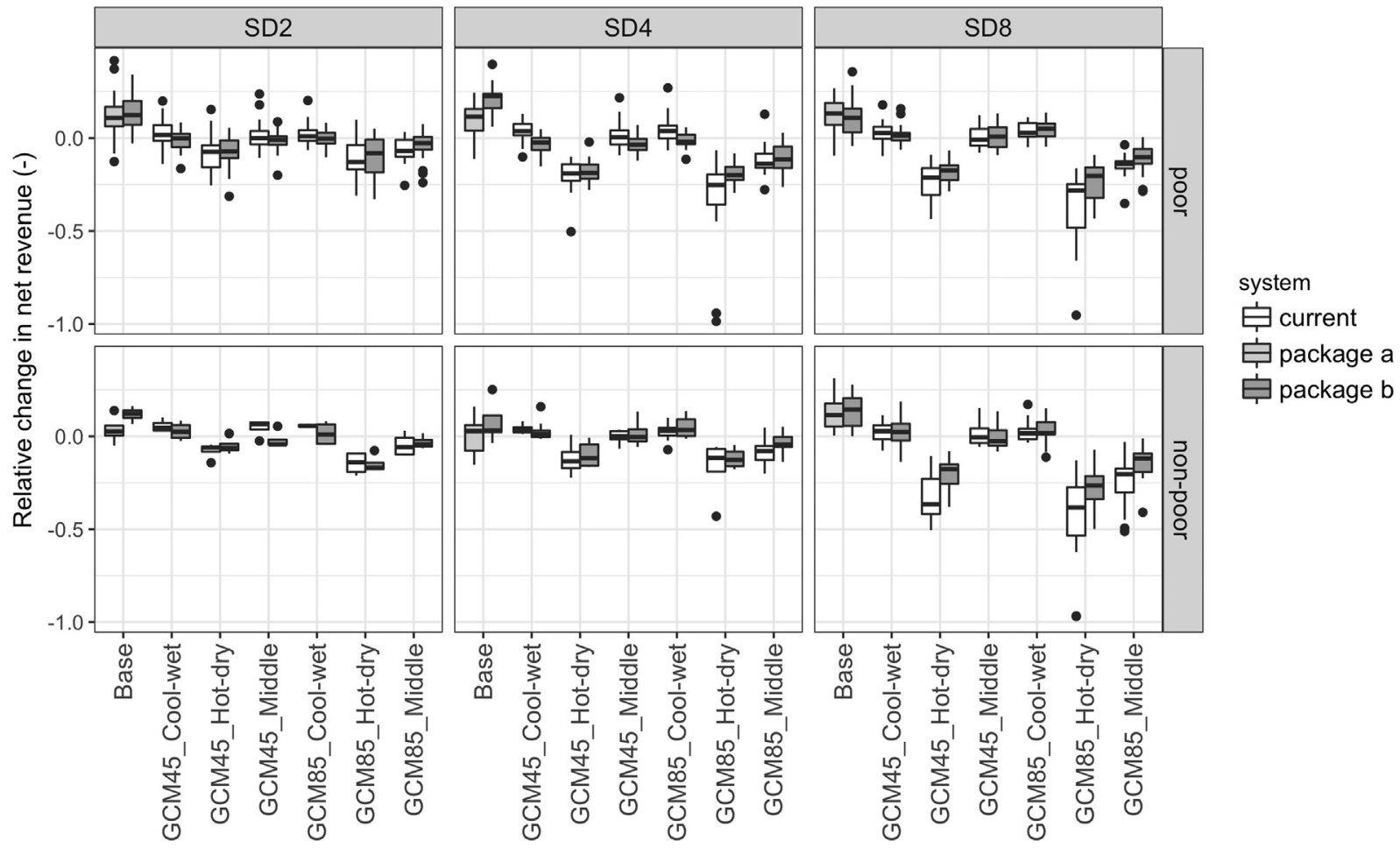

package b

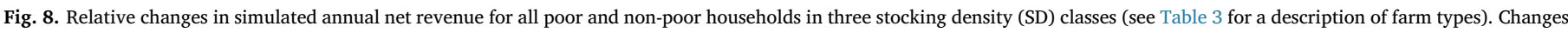

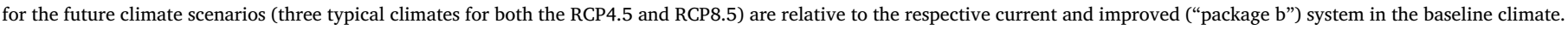
The leftmost boxplots indicate the relative change for "package a" and "package b" compared to the current system, both in the baseline climate. 


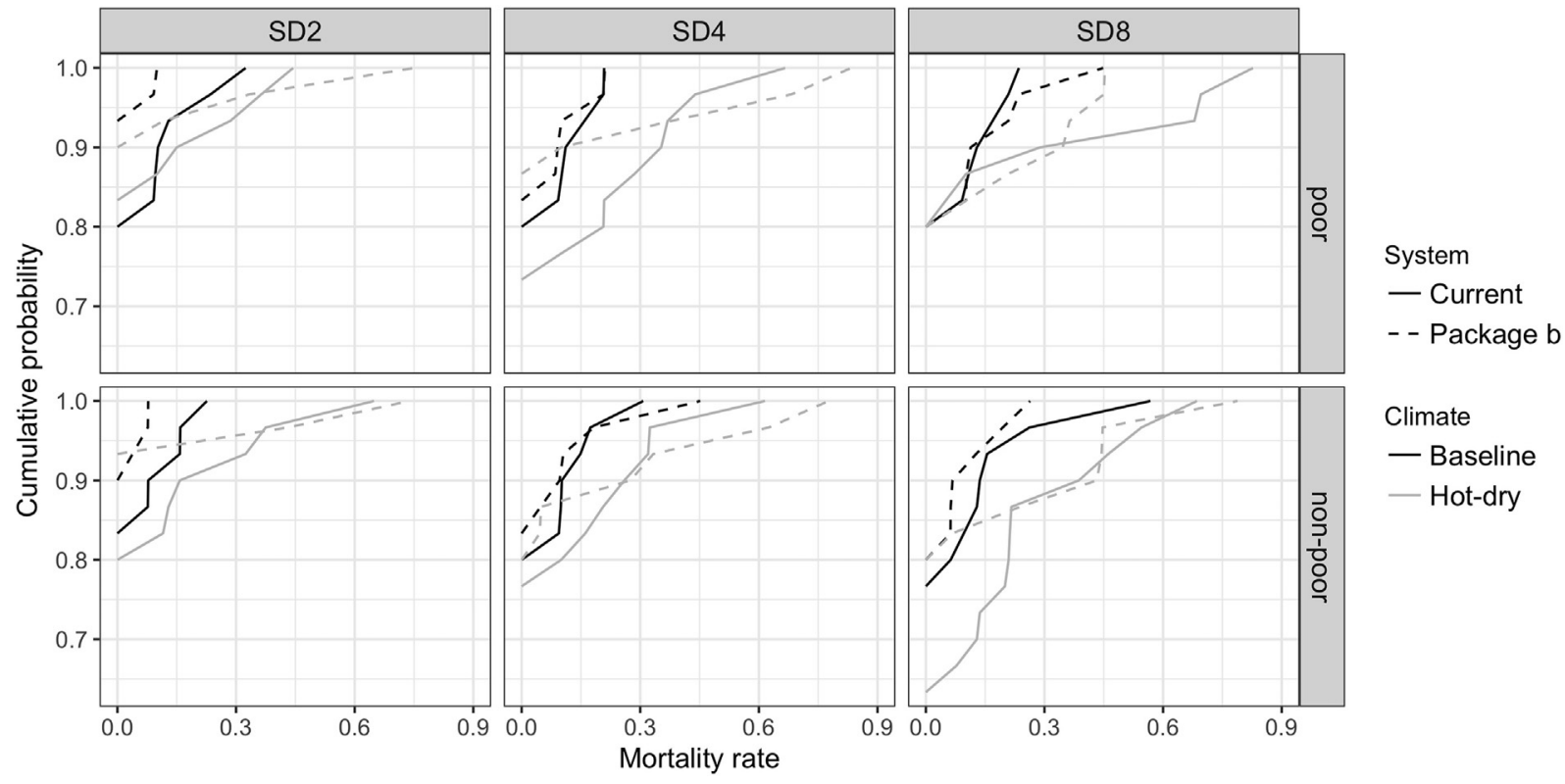

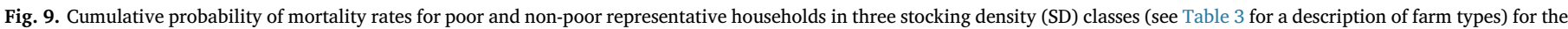
current and the improved system ("package b") in the baseline climate and the "hot-dry" climate of RCP8.5.

\section{Discussion}

Smallholder African farmers are widely believed to be vulnerable to the adverse effects of climate change (Descheemaeker et al., 2016a). More specifically, rainfed crop-livestock systems in arid and semiarid southern Africa were mapped as vulnerable hotspots (Thornton et al., 2008). Our integrated process-based modelling analysis revealed that the sensitivity to climate change of livestock contributes to this vulnerability in mixed systems. In several of the tested climate scenarios, livestock production and net revenues decreased, while at

(a)
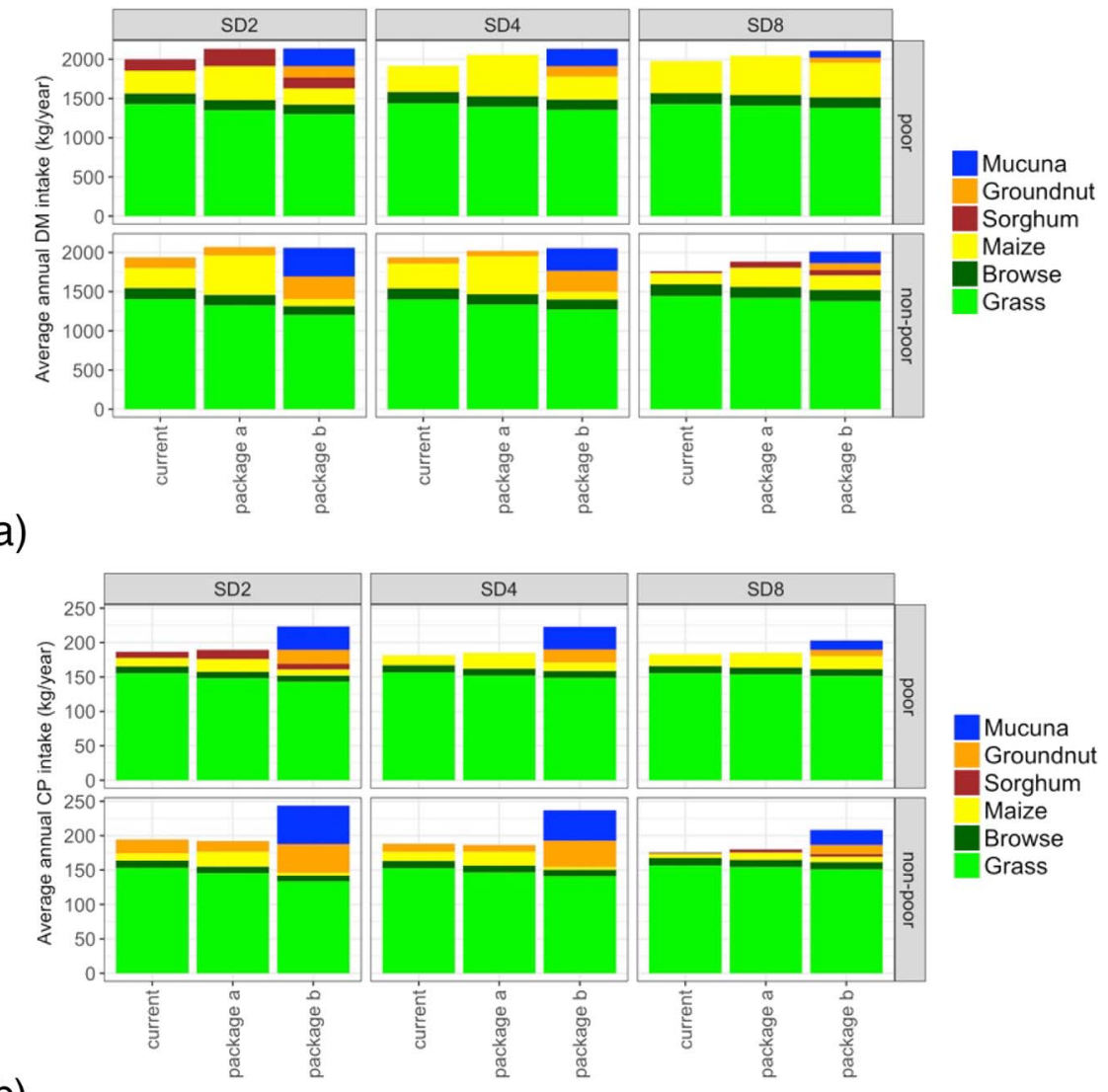

(b)

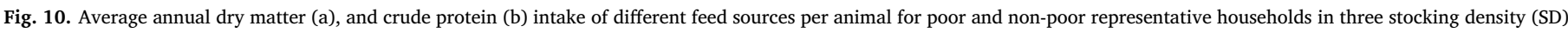

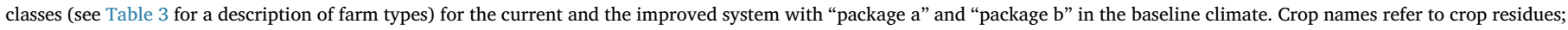
proportions and changes in metabolizable energy not shown but comparable to dry matter in (a). 


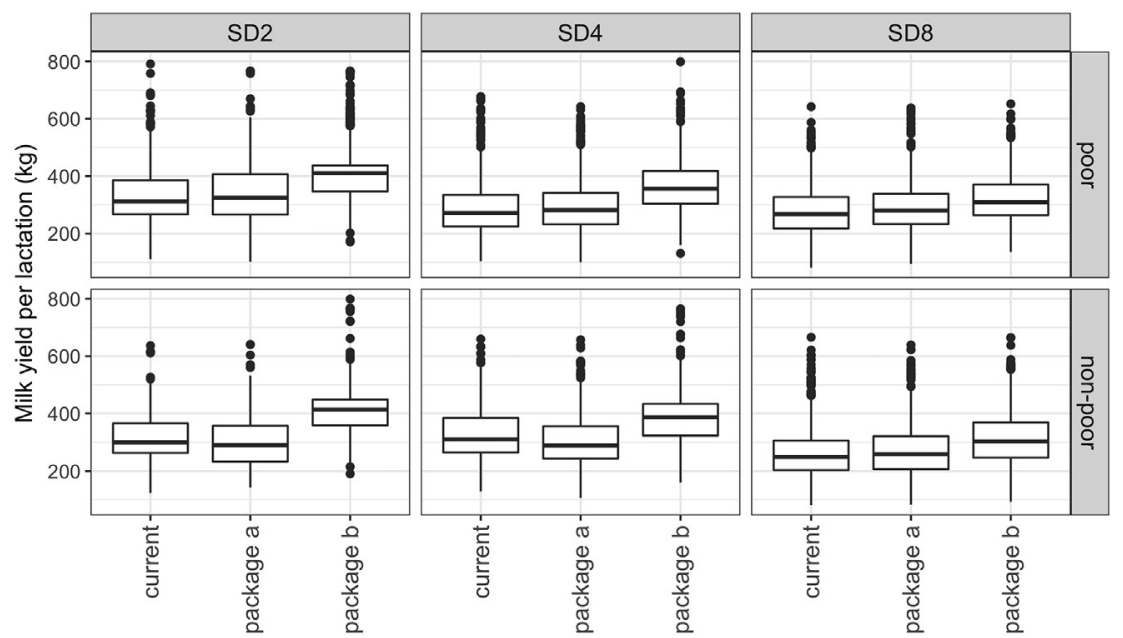

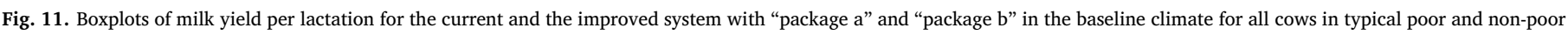
representative households in three stocking rate (SD) classes (see Table 3 for a description of farm types).

the same time risk increased. Like others highlighted for crops (e.g. Traore et al., 2017), we showed that also for livestock there is considerable uncertainty related to climate projections. Based on a range of potential changes, we quantified impacts from slightly positive in "cool-wet" to clearly negative in "hot-dry" scenarios. Varying income losses from African livestock farms were also predicted based on a Ricardian analysis (Seo and Mendelsohn, 2008). Using a similar approach for South Africa, Tibesigwa et al. (2015) found that specialized livestock and crop farmers were vulnerable to climate change, but crop-livestock farmers were not, a finding not supported by our analysis. Whereas some examples are available from global studies (e.g. Weindl et al., 2015) or other continents (e.g. Ghahramani and Moore, 2016), very few studies on African agriculture use dynamic simulation models to assess the likely impacts of climate change on livestock. An exception is the dynamic systems model of Dougill et al. (2010), predicting that climate change will exacerbate the decline in cattle herds and income from livestock in the Kalahari pastoral systems. Another, large-scale study on dryland livestock systems in West and East Africa used a combination of biophysical and socio-economic models showing that future drier conditions could reduce meat production by $14 \%$ (de Haan et al., 2016). Descriptions of climate change perceptions and current adaptations are more common in African studies, and several of those assess livestock systems (e.g. Silvestri et al., 2012; Megersa et al., 2014; Zampaligré et al., 2014). Although these studies do not quantitatively predict the future impact of climate change or adaptation, they offer insight into current trends and strategies. Farmers commonly perceive rainfall to become less in amount, less predictable, shorter in duration, and droughts to become more frequent, even though these perceptions are not always corroborated by climate records. Livestock keepers generally confirm the negative implications on feed availability and the repercussions on mortality, herd size, and animal performance (Silvestri et al., 2012; Megersa et al., 2014; Zampaligré et al., 2014). In other studies, negative impacts on livestock are inferred from anticipated changes in temperature, feed and water availability and animal diseases (e.g. Claessens et al., 2012). These and our findings on livestock systems' vulnerability alert preparing for a future in which livestock may become increasingly important because of widespread shifts from cropping to livestock keeping (Jones and Thornton, 2009) and increasing demands for livestock products (OECD/FAO, 2016; de Haan et al., 2016) across Africa.

We assessed the effects of climate change indirectly through the effects on the feedbase, an approach also followed in other processbased modelling studies (Weindl et al., 2015). This means firstly that our results depend on the representation of the feedbase. Simulated intake from rangelands and crop residues contributed $78-91 \%$ and $22-9 \%$ of the annual diet respectively, depending on the stocking density. This is in the range reported for African mixed systems (Valbuena et al., 2015). However, the contributions of grazing and residues we found are larger and smaller respectively than the broad averages $(50-55 \%$ for grazing and $30-35 \%$ for residues) reported by Herrero et al. (2013) for mixed rainfed systems in the African drylands. This discrepancy corroborates the relatively limited expansion of cultivated land, and the low livestock density and cropping intensity characterizing the agricultural system of Nkayi (Homann-Kee Tui et al., 2013b; Valbuena et al., 2015). Further, our diagnosis that the dry season feed gap is primarily caused by a lack of protein is confirmed in reports on the potential of legume forage options for Zimbabwean livestock production systems (Mapiye et al., 2007; Gwiriri et al., 2016).

Secondly, our indirect approach through the feedbase probably underestimated climate change impacts as the effects of heat stress, changes in water availability and pests and diseases (Thornton et al., 2009) were ignored. Another source of underestimation relates to the climate data, which did not capture possible changes in extreme events and variability. Although livestock can exploit variability in fodder availability to some extent, mortality and forced offtake in drought years lead to declines in herd size, which can persist for several seasons, unlike the shorter recovery time after crop failure. As climate change is expected to increase weather variability and frequency of extreme events (Porter et al., 2014), this risk needs to be better understood (Thornton et al., 2014), and investigated also for livestock (Naess and Bardsen, 2013). Further, coping with climate risk can be improved by including small ruminants, who play an important role for smallholders currently (Dube et al., 2014), and likely more so with climate change (Seo and Mendelsohn, 2008). As LIVSIM was recently adapted for goats (Amole et al., 2016), this can now be tested with the current modelling framework. Finally, instead of the grassland model used here, more detailed rangeland models (see Tietjen and Jeltsch (2007) for an overview) could be used if the necessary data on these environments becomes available for calibration and testing. Future developments could contribute by modelling browse intake, animal-vegetation interactions, and effects of climate change on woody vegetation production and species composition, and by accounting for spatial differentiation in productivity.

As we assessed impacts on livestock through effects on the feedbase, we tested feed interventions, acknowledging that adaptation may be achieved also through adapted breeds and livestock species, and animal and herd management (Silvestri et al., 2012). The adaptation packages consisted of combinations of technical options benefiting the three pillars of climate-smart agriculture through intensification and diversi- 
fication (Thornton et al., 2007; Descheemaeker et al., 2016a). The packages were deemed feasible and promising in the current context of semi-arid Zimbabwe for the following reasons. No trade-off with food self-sufficiency was anticipated as a minimum area of cereals was maintained and $40 \%$ of the income from livestock is reported to be invested in food (Dube et al., 2014). The modest fertilizer rates $\left(20 \mathrm{~kg} \mathrm{~N} \mathrm{ha}^{-1}\right)$ were affordable and sufficient manure was produced to apply at least $1 \mathrm{tha}^{-1}$ on the cereal crops, if manure would be properly collected and stored (Table 5). Increasing the area of groundnut was a promising strategy as groundnut is becoming a cash crop in Zimbabwe (Homann-Kee Tui et al., 2015b), with also the haulms fetching high prices on African markets because of their feeding quality (Ayantunde et al., 2014). Dedicating part of the farm to the forage crop mucuna is gradually becoming a common practice in the study area (Homann-Kee Tui et al., 2015a), as livestock markets are fast developing (Orr and Mausch, 2014). Finally, leaving sufficient amounts of crop residues as a mulch for conservation agriculture instead of livestock feeding was deemed unfeasible in this region (Valbuena et al., 2015; Homann-Kee Tui et al., 2015a).

Our simulations suggested benefits from crop-livestock integration under climate risk. Integrated soil fertility management and cropland diversification with grain and forage legumes improved livestock productivity and reduced risk and sensitivity to climate change, corresponding to other reported expectations (Thornton and Herrero, 2014). Thanks to improved animal productivity (Fig. 11), current production could be maintained while reducing herd sizes by about $20 \%$, illustrating that the tested intensification options can enable a shift towards keeping less, but more productive animals. This would have additional benefits in terms of reducing greenhouse gas emissions and water use per unit of product (Tarawali et al., 2011; Oosting et al., 2014), and reducing pressure on grazing resources. While alleviating feed gaps is effective and profitable in theory, it is complicated in practice, as illustrated by the widespread non-adoption of wellresearched forage and feed solutions (Sumberg, 2002). Limits and constraints to the adoption of climate adaptation options were reviewed earlier for African crop-livestock systems in general (Descheemaeker et al., 2016a). For semi-arid Zimbabwe specifically, poor access to inputs, services and knowledge as well as poor access to output markets are major barriers (Homann-Kee Tui et al., 2015a). Furthermore, our study illustrated that the multi-functionality of livestock acts as an incentive for keeping large herds, which guarantee large net revenues. However, as larger stocking densities result in more severe feed gaps, they also impair animal productivity and increase the sensitivity to climate change. Nevertheless, stocking densities are unlikely to be reduced as long as open-access grazing policies prevail (Gebremedhin et al., 2004) and farmers have poor access to banking, insurance and farm mechanization services, which could replace the traditional livestock functions (Descheemaeker et al., 2016a). As smallholders are currently mostly disconnected from market dynamics, the increasing regional demand in animal protein is projected to be largely met by imports (OECD/FAO, 2016). Reversing this by enabling smallholders to tap into the potential through sustainable and climate-smart intensification, will require policies directed at market functioning and access, smallholders' capacity in market participation, infrastructure improvements, affordable input prices and credit schemes, tailored information and extension services, including meteorological services and early warning systems (Tarawali et al., 2011; Silvestri et al., 2012).

\section{Conclusions}

Our modelling framework integrating climate, crop, rangeland and farm management information enabled the assessment of climate change and adaptation effects on livestock production. We quantified effects on a range of livestock production indicators, which is essential in the smallholder context where farmers keep livestock for many functions besides meat and milk. Furthermore, our analysis captured the heterogeneity in the farm population, showing that households are affected differently by changes in the climate and by management interventions. Through such disaggregated analysis, our framework generates essential information for effective targeting of solutions towards climate resilience. Comparing the effects of contrasting climate scenarios illustrated the typical uncertainty in climate impact assessments and highlighted the vulnerability of the livestock component of mixed systems. The current poor livestock productivity in the study area was related to dry-season feed gaps, as animals rely on grazing and low-quality crop residues. These feed gaps also explain the sensitivity to climate change. A comparison of two adaptation packages revealed that improving the quality of the feed through crop diversification with legumes raised animal productivity and reduced vulnerability. Climatesmart livestock production would require keeping less but better fed and hence more productive animals. However, such a transition needs to be enabled by changes in the institutional context, including rural banking and insurance services, functioning markets, and improved access to agricultural inputs.

\section{Acknowledgements}

This study was conducted as part of the Crop Livestock Intensification Project (CLIP), which is one component of the Regional Integrated Assessment project (RIA, www.agmip.org) of AGMIP. The UK Department for International Development (UKAID) (GB-1-202108) funded the research. The household data for this paper were generated by the study on 'Optimizing livelihood and environmental benefits from crop residues in smallholder crop-livestock system in Sub-Saharan Africa and South Asia: South African case study', supported by the Systemwide Livestock Programme (SLP, HomannKee Tui et al., 2013a). We thank the CGIAR Research Programs Resilient Dryland Systems and Policies, Institutions and Markets for support. We are grateful to communities in Nkayi district and Matabeleland North stakeholders, Zimbabwe, for their contributions.

\section{References}

Agricultural Model Inter-comparison and Improvement Project (AgMIP), 2015. Guide for Regional Integrated Assessments: Handbook of Methods and Procedures. Version 6.0. http://www.agmip.org/wp-content/uploads/2015/09/AgMIP-RIA-Protocols-V6sm. pdf last accessed on 30 October 2016.

Amole, T.A., Zijlstra, M., Descheemaeker, K., Ayantunde, A.A., Duncan, A.J., 2016. Assessment of lifetime performance of small ruminants under different feeding systems. Animal 1-9 First View.

Antle, J.M., Valdivia, R.O., Boote, K.J., Janssen, S., Jones, J.W., Porter, C.H., Rosenzweig, C., Ruane, A.C., Thorburn, P.J., 2015. AgMIP's trans-disciplinary agricultural systems approach to regional integrated assessment of climate impact, vulnerability and adaptation. In: Rosenzweig, C., Hillel, D. (Eds.), Handbook of Climate Change and Agroecosystems: The Agricultural Model Intercomparison and Improvement Project Integrated Crop and Economic Assessments, Part 1. Imperial College Press, London.

Antle, J., Homann-Kee Tui, S., Descheemaeker, K., Masikati, P., 2016. Using AgMIP regional integrated assessment methods to evaluate climate impact, adaptation, vulnerability and resilience in agricultural systems. In: Zilberman, D., Lipper, L., McCarthy, N., Asfaw, S., Branca, G. (Eds.), Climate Smart Agriculture - Building Resilience to Climate Change. Elsevier Book chapter. (in press).

Ayantunde, A.A., Blümmel, M., Grings, E., Duncan, A.J., 2014. Price and quality of livestock feeds in suburban markets of West Africa's Sahel: case study from Bamako, Mali. Rev. Elev. Med. Vet. Pays Trop. 67, 13-21.

Claessens, L., Antle, J.M., Stoorvogel, J.J., Valdivia, R.O., Thornton, P.K., Herrero, M., 2012. A method for evaluating climate change adaptation strategies for small-scale farmers using survey, experimental and modeled data. Agric. Syst. 111, 85-95.

DAGRIS, 2007. In: Kemp, S., Mamo, Y., Asrat, B., Dessie, T. (Eds.), Domestic Animal Genetic Resources Information System (DAGRIS). International Livestock Research Institute, Addis Ababa, Ethiopia. http://dagris.ilri.cgiar.org last accessed on 30 October 2016.

Descheemaeker, K., Oosting, S.J., Homann Kee-Tui, S., Masikati, P., Falconnier, G.N., Giller, K.E., 2016a. Climate change adaptation and mitigation in smallholder crop-livestock systems in sub-Saharan Africa: a call for integrated impact assessments. Reg. Environ. Chang. 16, 2331-2343.

Descheemaeker, K., Ronner, E., Ollenburger, M., Franke, A.C., Klapwijk, C.J., Falconnier, G.N., Wichern, J., Giller, K.E., 2016b. Which options fit best? Operationalizing the socio-ecological niche concept. Exp. Agric (in press).

Dougill, A.J., Fraser, E.D.G., Reed, M.S., 2010. Anticipating vulnerability to climate change in dryland pastoral systems: using dynamic systems models for the Kalahari. 
Ecol. Soc. 15, 17.

Dube, T., Homann-Kee Tui, S., van Rooyen, A., Rodriguez, D., 2014. Baseline and Situation Analysis Report: Integrating Crop and Livestock Production for Improved Food Security and Livelihoods in Rural Zimbabwe. Socioeconomics Discussion Paper Series, vol. 29 ICRISAT, Patancheru.

Dye, P.J., Spear, P.T., 1982. The effect of bush clearing and rainfall variability on grass yield and composition in South West Zimbabwe. Zimb. J. Agric. Res. 20, 103-118.

van Garderen, A.E.R.M., 2011. (Re-)considering cattle farming in southern Africa under a changing climate. Weather Clim. Soc. 3, 249-253.

Garwe, E.C., 2001. Reproductive performance of crossbred cattle developed for milk production in the semi-arid tropics and the effect of feed supplementation. (PhD thesis) University of Zimbabwe.

Gebremedhin, B., Pender, J., Tesfay, G., 2004. Collective action for grazing land management in crop-livestock mixed systems in the highlands of northern Ethiopia. Agric. Syst. 82, 273-290.

Ghahramani, A., Moore, A.D., 2016. Impact of climate changes on existing crop-livestock farming systems. Agric. Syst. 146, 142-155.

Giller, K.E., Tittonell, P., Rufino, M.C., van Wijk, M.T., Zingore, S., Mapfumo, P., AdjeiNsiah, S., Herrero, M., Chikowo, R., Corbeels, M., Rowe, E.C., Baijukya, F., Mwijage, A., Smith, J., Yeboah, E., van der Burg, W.J., Sanogo, O.M., Misiko, M., de Ridder, N., Karanja, S., Kaizzi, C., K'ungu, J., Mwale, M., Nwaga, D., Pacini, C., Vanlauwe, B., 2011. Communicating complexity: Integrated assessment of trade-offs concerning soil fertility management within African farming systems to support innovation and development. Agric. Syst. 104, 191-203.

Godber, O.F., Wall, R., 2014. Livestock and food security: vulnerability to population growth and climate change. Glob. Chang. Biol. 20, 3092-3102.

Gwiriri, L.C., Manyawu, G., Mashanda, P.B., Chakoma, I., Moyo, S., Chakoma, C., Sethaunyane, H., Imbayarwo-Chikosi, V.E., Dube, S., Maasdorp, B.V., 2016. The potential of replacing conventional dairy supplements with forage legume-based diets in Zimbabwe's smallholder dairy sector. Afr. J. Range Forage Sci. 33, 155-163.

de Haan, C., Cervigni, R., Mottet, A., Conchedda, G., Gerber, P., Msangi, S., Lesnoff, M., Ham, F., Fillol, E., Nigussie, K., 2016. Vulnerability and resilience in livestock systems in the drylands of Sub-Saharan Africa. In: De Haan, C. (Ed.), Prospects for Livestock-based Livelihoods in Africa's Drylands. World Bank Studies. World Bank, Washington, DC, pp. 79-122.

Herrero, M., Thornton, P.K., Notenbaert, A.M., Wood, S., Msangi, S., Freeman, H.A., et al., 2010. Smart investments in sustainble food production. Revisiting mixed croplivestock systems. Science 327, 822-825.

Herrero, M., Havlik, P., Valin, H., Notenbaert, A., Rufino, M.C., Thornton, P.K., Blümmel, M., Weiss, F., Grace, D., Obersteiner, M., 2013. Biomass use, production, feed efficiencies, and greenhouse gas emissions from global livestock systems. Proc. Natl. Acad. Sci. 110, 20888-20893.

Holzworth, D.P., Huth, N.I., deVoil, P.G., Zurcher, E.J., Herrmann, N.I., McLean, G., Chenu, K., van Oosterom, E.J., Snow, V., Murphy, C., Moore, A.D., Brown, H., Whish, J.P.M., Verrall, S., Fainges, J., Bell, L.W., Peake, A.S., Poulton, P.L., Hochman, Z., Thorburn, P.J., Gaydon, D.S., Dalgliesh, N.P., Rodriguez, D., Cox, H., Chapman, S., Doherty, A., Teixeira, E., Sharp, J., Cichota, R., Vogeler, I., Li, F.Y., Wang, E., Hammer, G.L., Robertson, M.J., Dimes, J.P., Whitbread, A.M., Hunt, J., van Rees, H., McClelland, T., Carberry, P.S., Hargreaves, J.N.G., MacLeod, N., McDonald, C. Harsdorf, J., Wedgwood, S., Keating, B.A., 2014. APSIM - evolution towards a new generation of agricultural systems simulation. Environ. Model Softw. 62, 327-350.

Homann-Kee Tui, S., Bandason, E., Maute, F., Nkomboni, D., Mpofu, N., Tanganyika, J., van Rooyen, A., Gondwe, T., Dias, P., Ncube, S., Moyo, S., Hendricks, S., Nisrane, F., 2013a. Optimizing Livelihood and Environmental Benefits from Crop Residues in Smallholder Crop-livestock Systems in Southern Africa. ICRISAT, Socioeconomics Discussion Paper Series, vol. 11 ICRISAT, Patancheru.

Homann-Kee Tui, S., Blümmel, M., Valbuena, D., Chirima, A., MASIKATI, P., van Rooyen, A.F., Kassie, G.T., 2013b. Assessing the potential of dual-purpose maize in southern Africa: a multi-level approach. Field Crop Res. 153, 37-51.

Homann-Kee Tui, S., Valbuena, D., Patricia Masikati, P., Descheemaeker, K., Nyamangara, J., Claessens, L., Erenstein, O., van Rooyen, A., Nkomboni, D., 2015a. Economic trade-offs of biomass use in crop-livestock systems: exploring more sustainable options in semi-arid Zimbabwe. Agric. Syst. 134, 48-60.

Homann-Kee Tui, S., van Rooyen, A., Dube, T., Kudita, S., Kondwakwenda, A., Madzonga, O., Masendeke, D., Savemore, N.N., Muhambi, M., 2015b. Partnerships for unlocking potentials in groundnut value chains in Zimbabwe. In: ICRISAT Research Brief, . http://www.icrisat.org/PDF/Groundnut-Value-Chains-in-Zimbabwe.pdf.

Illius, A.W., Magadzire, Z., Mukungurutse, E., 2000. Browse production and utilisation. In: Proceedings of the 3rd Livestock Production Programme Zimbabwe Projects Workshop, Ingwe Lodge, Matobo, Zimbabwe, pp. 26-28 September 2000.

Jones, P.G., Thornton, P.K., 2009. Croppers to livestock keepers: livelihood transitions to 2050 in Africa due to climate change. Environ. Sci. Pol. 12, 427-437.

Kelly, R.D., Walker, B.H., 1976. The effects of different forms of land use on the ecology of a semi-arid region in southeastern Rhodesia. J. Ecol. 73, 235-253.

Lipper, L., Thornton, P., Campbell, B.M., Baedeker, T., Braimoh, A., Bwalya, M., Caron, P., Cattaneo, A., Garrity, D., Henry, K., Hottle, R., Jackson, L., Jarvis, A., Kossam, F., Mann, W., McCarthy, N., Meybeck, A., Neufeldt, H., Remington, T., Sen, P.T., Sessa, R., Shula, R., Tibu, A., Torquebiau, E.F., 2014. Climate-smart agriculture for food security. Nat. Clim. Chang. 4, 1068-1072.

Mapiye, C., Mwale, M., Mupangwa, J.F., Mugabe, P.H., 2007. Utilisation of ley legumes as livestock feed in Zimbabwe. Trop. Grassl. 41, 84-91.

Masikati, P., 2011. Improving the Water Productivity of Integrated Crop-livestock Systems in the Semi-arid Tropics of Zimbabwe: Ex-ante Analysis Using Simulation Modeling. (PhD thesis) ZEF, Bonn 154 p.

Masikati, P., Manschadi, A., van Rooyen, A., Hargreaves, J., 2013. Maize-mucuna rotation: a technology to improve water productivity in smallholder farming systems.
Agric. Syst. 123, 62-70.

Masikati, P., Homann-Kee Tui, S., Descheemaeker, K., Crespo, O., Walker, S., Lennard, C.J., Claessens, L., Gama, A.C., Famba, S., van Rooyen, A.F., Valdivia, R.O., 2015. Crop-livestock intensification in the face of climate change: exploring opportunities to reduce risk and increase resilience in Southern Africa by using an integrated multimodeling approach. In: Rosenzweig, C., Hillel, D. (Eds.), Handbook of Climate Change and Agroecosystems: The Agricultural Model Intercomparison and Improvement Project Integrated Crop and Economic Assessments, Part 2. Imperial College Press, London, pp. 159-198.

McKeon, G.M., Ash, A.J., Hall, W.B., Stafford Smith, M., 2000. Simulation of grazing strategies for beef production in north-east Queensland. In: Hammer, G., Nicholls, N., Mitchell, C. (Eds.), Applications of Seasonal Climate Forecasting in Agricultural and Natural Ecosystems-The Australian Experience. Kluwer Academic Press, Netherlands, pp. 227-252.

McKeon, G.M., Stone, G.S., Syktus, J.I., Carter, J.O., Flood, N.R., Ahrens, D.G., Bruget, D.N., Chilcott, C.R., Cobon, D.H., Cowley, R.A., Crimp, S.J., Fraser, G.W., Howden, S.M., Johnston, P.W., Ryan, J.G., Stokes, C.J., Day, K.A., 2009. Climate change impacts on northern Australian rangeland livestock carrying capacity: a review of issues. Rangel. J. 31, 1-29.

Megersa, B., Markemann, A., Angassa, A., Ogutu, J.O., Piepho, H.-P., Zaráte, A.V., 2014. Agricultural systems. Agric. Syst. 130 (C), 23-34.

Mekonnen, S., Descheemaeker, K., Tolera, A., Amede, T., 2011. Livestock water productivity in a water stressed environment in northern Ethiopia. Exp. Agric. 47 (S1), 85-98.

Moll, H.A.J., 2005. Costs and benefits of livestock systems and the role of market and nonmarket relationships. Agric. Econ. 32, 181-193.

Naab, J., Bationo, A., Wafula, B.M., Traore, P.S., Zougmore, R., Outtara, M., Tabo, R., Vlek, P.L.G., 2012. African perspective on climate change and agriculture: impacts, adaptation and mitigation potential. In: Rosenzweig, C., Hillel, D. (Eds.), Handbook of Climate Change and Agroecosystems: Global and Regional Aspects and Implications. Imperial College Press, London, pp. 103-124.

Naess, M.W., Bardsen, B.-J., 2013. Why herd size matters - mitigating the effects of livestock crashes. PLoS One 8 (8), 1-7.

Ngongoni, N.T., Mapiye, C., Mwale, M., Mupeta, B., 2006. Factors affecting milk production in the smallholder dairy sector of Zimbabwe. Livest. Res. Rural. Dev. 18 (5), 2006.

Niang, I., Ruppel, O.C., Abdrabo, M.A., Essel, A., Lennard, C., Padgham, J., Urquhart, P., 2014. Africa. In: Barros, V.R. (Ed.), Climate Change 2014: Impacts, Adaptation, and Vulnerability. Part B: Regional Aspects. Contribution of Working Group II to the Fifth Assessment Report of the Intergovernmental Panel on Climate Change. Cambridge University Press, Cambridge and New York, NY, pp. 1199-1265.

OECD/FAO, 2016. OECD-FAO Agricultural Outlook 2016-2025. OECD Publishing, Paris.

Oosting, S.J., Udo, H.M.J., Viets, T.C., 2014. Development of livestock production in the tropics: farm and farmers' perspectives. Animal 8, 1238-1248.

Orr, A., Mausch, K., 2014. How can we make smallholder agriculture in the semi-arid tropics more profitable and resilient? In: ICRISAT Socio-economic White Paper. ICRISAT.

Porter, J.R., Xie, L., Challinor, A.J., Cochrane, K., Howden, S.M., Iqbal, M.M., Lobell, D.B., Travasso, M.I., 2014. Food security and food production systems. In: Field (Ed.), Climate Change 2014: Impacts, Adaptation, and Vulnerability. Part A: Global and Sectoral Aspects. Contribution of Working Group II to the Fifth Assessment Report of the Intergovernmental Panel on Climate Change. Cambridge University Press, Cambridge and New York, NY, pp. 485-533.

Rickert, K.G., Stuth, J.W., McKeon, G.M., 2000. Modelling pasture and animal production. In: 't Mannetje, L., Jones, R.M. (Eds.), Field and Laboratory Methods for Grassland and animal Production Research. CABI, New York, pp. 29-66.

Rodriguez, D., de Voil, P., Rufino, M.C., Odendo, M., van Wijk, M.T., 2017. To mulch or to munch? Big modelling of big data. Agric. Syst. 153, 32-42.

Ruane, A.C., McDermid, S.P., 2017. Selection of a representative subset of global climate models that captures the profile of regional changes for integrated climate impacts assessment. Earth Perspect. 4, 1.

Ruane, A.C., Winter, J.M., McDermid, S.P., Hudson, N.I., 2015. AgMIP climate data and scenarios for integrated assessment. In: Rosenzweig, C., Hillel, D. (Eds.), Handbook of Climate Change and Agroecosystems: The Agricultural Model Intercomparison and Improvement Project Integrated Crop and Economic Assessments, Part 2. Imperial College Press, London, pp. 45-78.

Rufino, M.C., Herrero, M., van Wijk, M.T., Hemerik, L., de Ridder, N., Giller, K.E., 2009. Lifetime productivity of dairy cows in smallholder farming systems of the highlands of Central Kenya. Animal 3, 1044-1056.

Rufino, M.C., Dury, J., Tittonell, P., van Wijk, M.T., Herrero, M., Zingore, S., Mapfumo, P., Giller, K.E., 2011. Competing use of organic resources village-level interactions between farm types and climate variability in a communal area of NE Zimbabwe. Agric. Syst. 104, 175-190.

Rutherford, M.C., 1978. Primary production ecology in southern Africa. In: Werger, M.J.A. (Ed.), Biogeography and Ecology of Southern Africa. Junk, the Hague, pp. 621-659.

Scoones, I., 1995. Exploiting heterogeneity: habitat use by cattle in dryland Zimbabwe. J. Arid Environ. 29, 221-237.

Seo, S.N., Mendelsohn, R., 2008. Measuring impacts and adaptations to climate change: a structural Ricardian model of African livestock management. Agric. Econ. 38, 151-165.

Silvestri, S., Bryan, E., Ringler, C., Herrero, M., Okoba, B., 2012. Climate change perception and adaptation of agro-pastoral communities in Kenya. Reg. Environ. Chang. 12, 791-802.

Stokes, C., Marshall, N., Macleod, N., 2012. Developing Improved Industry Strategies and Policies to Assist Beef Enterprises Across Northern Australia Adapt to a Changing and 
More Variable Climate. Meat and Livestock Australia Limited, North Sydney, NSW 95p.

Sumberg, J., 2002. The logic of fodder legumes in Africa. Food Policy 27, 285-300. Tarawali, S., Herrero, M., Descheemaeker, K., Grings, E., Blümmel, M., 2011. Pathways for sustainable development of mixed crop livestock systems: taking a livestock and pro-poor approach. Livest. Sci. 139, 11-21.

Taylor, K.E., Stouffer, R.J., Meehl, G.A., 2012. An overview of CMIP5 and the experiment design. Bull. Am. Meteorol. Soc. 93, 485-498.

Thornton, P.K., Herrero, M., 2014. Climate change adaptation in mixed crop-livestock systems in developing countries. Glob. Food Sec. 3, 99-107.

Thornton, P.K., Boone, R.B., Galvin, K.A., BurnSilver, S.B., Waithaka, M.M., Kuyiah, J., Karanja, S., González-Estrada, E., Herrero, M., 2007. Coping strategies in livestockdependent households in east and southern Africa: a synthesis of four case studies. Hum. Ecol. 35, 461-476.

Thornton, P.K., Jones, P.G., Owiyo, T., Kruska, R.L., Herrero, M., Orindi, V., Bhadwal, S., Kristjanson, P., Notenbaert, A., Bekele, N., Omolo, A., 2008. Climate change and poverty in Africa: mapping hotspots of vulnerability. Afr. J. Agric. Resour. Econ. 2 24-44.

Thornton, P.K., van de Steeg, J., Notenbaert, A., Herrero, M., 2009. The impacts of climate change on livestock and livestock systems in developing countries: a review of what we know and what we need to know. Agric. Syst. 101, 113-127.
Thornton, P.K., Ericksen, P.J., Herrero, M., Challinor, A.J., 2014. Climate variability and vulnerability to climate change: a review. Glob. Chang. Biol. 20, 3313-3328.

Tibesigwa, B., Visser, M., Turpie, J., 2015. The impact of climate change on net revenue and food adequacy of subsistence farming households in South Africa. Environ. Dev. Econ. 20, 327-353.

Tietjen, B., Jeltsch, F., 2007. Semi-arid grazing systems and climate change: a survey of present modelling potential and future needs. J. Appl. Ecol. 44, 425-434.

Traore, B., Descheemaeker, K., van Wijk, M.T., Corbeels, M., Supit, I., Giller, K.E., 2017. Modelling cereal crops to assess future climate risk for family food self-sufficiency in southern Mali. Field Crop Res. 201, 133-145.

Valbuena, D., Tui, S.H.-K., Erenstein, O., Teufel, N., Duncan, A., Abdoulaye, T., et al., 2015. Identifying determinants, pressures and trade-offs of crop residue use in mixed smallholder farms in Sub-Saharan Africa and South Asia. Agric. Syst. 134 (C), 107-118.

Weindl, I., Lotze-Campen, H., Popp, A., Müller, C., Havlík, P., Herrero, M., Schmitz, C., Rolinski, S., 2015. Livestock in a changing climate: production system transitions as an adaptation strategy for agriculture. Environ. Res. Lett. 10 094021-13.

Zampaligré, N., Dossa, L.H., Schlecht, E., 2014. Climate change and variability: Perception and adaptation strategies of pastoralists and agro-pastoralists across different zones of Burkina Faso. Reg. Environ. Chang. 14, 769-783.

ZimVAC, 2013. Rural livelihoods assessment, Harare. 